\title{
- Empreendimentos piscícolas e o médico veterinário
}

\section{Veterinarians and fish breeding}

Secretaria da Agricultura e Abastecimento Av. Francisco Matarazzo, 455 05001-000 - Sāo Paulo - SP

Tel.: (0xx11) 3871-7591

Fax: (0xx11) 3871-7568

Pesquisador Científico-nível 5

Instituto de Pesca

\section{RESUMO}

Este artigo tem o objetivo de mostrar aos colegas veterinários os procedimentos para a atuação em piscicultura. Trata-se de área nova para os colegas, mas que deve ser encarada como uma nova realidade. Nesse artigo, salientamos a importância do médico veterinário nesses estabelecimentos para se garantir a qualidade do produto produzido. Relatamos também as principais doenças que afetam os peixes cultivados, bem como orientamos na profilaxia e na terapêutica.

Unitermos: peixes, patologia, sanidade.

\section{Introdução}

A piscicultura é um dos segmentos da produção animal que mais cresce no mundo e no Brasil. Apesar de ser uma atividade relativamente nova, tem-se firmado cada vez mais como uma exploração economicamente rentável, visto que o capital inicial investido pode retornar em até um ano. FERRAZ (1995-96) afirma que, em um hectare, a produção pode ser acima de seis toneladas de peixes por ano.

Segundo MESQUITA (1996), nossas excelentes condições hidrográficas e climáticas são propícias para a aqüicultura brasileira e poderá dar condições a muitas famílias para fixação nas áreas produtoras, possibilitando a geração de empregos e melhoria das condições de vida; bastando, para isto, aproveitar o potencial aquático disponível: cerca de 5,2 milhões de hectares de água represadas para fins energéticos, de abastecimento, de irrigação e de controle de cheias, e um litoral de cerca de $8.000 \mathrm{~km}$, entrecortado de baías, lagoas e áreas planas, adequadas à implantação da maricultura.

A aqüicultura brasileira vem-se despontando como um agronegócio, porém constata-se um crescimento desordenado da atividade, acompanhado de um descontrole sanitário, o que tem colaborado com altas taxas de mortalidade e produção de pescado com qualidade duvidosa. Para a reversão desse quadro, é necessário o acom- panhamento veterinário com o planejamento do manejo zoosanitário, visando melhorar os baixos índices de produtividade, diminuir os custos de produção e proporcionar uma oferta regular do produto com qualidade para o consumidor. A produtividade pode ser aumentada se medidas higiênicas e sanitárias forem associadas às zootécnicas, pois, até o momento, nos empreendimentos aqüícolas brasileiros, a profilaxia vem sendo praticada de um modo precário.

A principal fonte de escoamento da produção piscícola no Brasil, diferente do que ocorre no resto do mundo, tem sido os pesqueiros comerciais, que recebem cerca de $90 \%$ da produção, sendo o restante distribuído em supermercados, peixarias, indústrias de processamento de filé e vendas direta ao consumidor. Acreditava-se, até então, que a produção de peixe seria para atender às indústrias processadoras. Nesse ínterim, inicia a atividade dos pesqueiros, que pagando melhor por quilo de peixe, desviou quase que toda a produção, ficando as indústrias processadoras sem condições de se manterem no mercado. É inegável a contribuição que os pesqueiros trazem para a atividade, pois propiciam, além do lazer, uma divulgação do produto, mas para a piscicultura como um todo é muito pouco.

Vemos que é um importante campo de atuação para a classe veterinária, pois há necessidade urgente de pro- 
fissional na orientação da atividade em toda cadeia produtiva, para garantir a qualidade do produto.

Só para exemplificar, em 1990, os danos causados por doenças estiveram entre 10 a $20 \%$ do valor da produção total da aqüicultura e acreditamos que, nos dias de hoje, essa porcentagem seja maior devido à introdução e disseminação de doenças, o que mostra a necessidade urgente da combinação do uso de medidas profiláticas e condutas terapêuticas apropriadas, visando-se melhores taxas de produtividade.

Para a instalação de doenças infecto-contagiosas e parasitárias num plantel, há necessidade de que seja deflagrado um estresse e esse quadro tem maior gravidade quanto mais debilitados estiverem os animais.

Embora a mortalidade seja o principal indicador de uma doença, esta vem precedida de um quadro clínico de menor ou maior duração.

A amostragem retirada do plantel onde está implantado o quadro clínico, pode orientar o diagnóstico ou assegurá-lo, baseando-se sempre nos parâmetros do meio ambiente (fatores físicos, químicos e biológicos) e nos conhecimentos patológicos antecedentes deste plantel.

Para facilitar o entendimento dos sintomas clínicos, é necessário conhecer o peixe em seu estado hígido. O peixe sadio mostra um conjunto de sinais que são facilmente identificados como reflexos: fogem rapidamente perante movimentos bruscos, luz e "barulho" próximos a ele (reflexo de fuga); os olhos movimentam-se para a posição de natação quando é retirado da água (reflexo dos olhos); os peixes, quando retirados da água, tendem a manter a nadadeira caudal em posição vertical (reflexo da cauda).

As alterações de comportamento ou sintomas afetam também as funções de relação e nutrição. As alterações de funções de relação transtornam o equilíbrio estático ou locomotor e estão relacionadas com a natação, que se torna lenta, desorientada e fora de sua postura peculiar, os peixes podem ficar isolados do cardume, apresentar hiperexcitabilidade ou total apatia. As funções de nutrição requerem apetite, quando o animal se mostra com anorexia, pode ser um indicador de doenças infecciosas, anemia, traumatismo oral.

Outras alterações como a do ritmo respiratório ou respiração superficial indica afecção branquial ou presença de alguma substância tóxica no ambiente aquático afetando diretamente os animais.

Podem, ainda, ser observadas lesões externas como malformações e deformações que afetam, em primeiro lugar, o estado geral e as proporções corporais, mas ocorrem, ainda, as trocas de pigmentação (melanose ou descoloração), o aparecimento de hemorragias subcutâneas e a palidez das brânquias, sintomas que traduzem agressões no plantel.

Nas doenças dos peixes, as manifestações clínicas são muito semelhantes entre si, raramente havendo um quadro patognomônico que seja indicativo de uma determinada doença. Assim, quando os peixes apresentam-se com ictiofitiriose, tricodiniose, girodactilidiose e dactilogirose, mostram a mesma sintomatologia: saltam a esmo, batem contra as paredes dos viveiros e, numa outra variedade de doenças, exibem, além dos sintomas mencionados, inapetência e projeção da mandíbula para a frente e nadam na superfície buscando melhorar a respiração. Quando a causa está relacionada com o meio ambiente, como a falta de oxigênio na água, os peixes também nadam na superfície, boquejando oxigênio. Essa sintomatologia é semelhante a que ocorre com a variação brusca de temperatura, variação de $\mathrm{pH}$ e presença de produtos químicos na água.

Como o ponto fundamental para preservar a saúde dos peixes é a prevenção, passaremos a discorrer sobre alguns cuidados higiênicos e sanitários referentes a água, alimentação, peixes, ovos, alevinos, com o meio onde vivem (viveiros) e enfim com toda a infra-estrutura da propriedade que deve ser respeitada para garantir a produção. (ALEXANDRINO, 1998).

\section{Cuidados com a água}

A água que abastece os viveiros deve ser, preferencialmente, originária de nascentes localizadas na propriedade e submetida periodicamente a análises para controle das características físicas, químicas e biológicas. Águas contaminadas com pesticidas, detergentes, metais pesados e esgotos domésticos não devem ser utilizadas em piscicultura, pois podem, além de contaminar o homem, promover doenças nos peixes. ALEXANDRINO et al. (1996b) relataram a ocorrência de carcinoma hepatocelular em tainhas da região estuarino-lagunar de Cananéia e, muito provavelmente, a origem desta neoplasia esteja relacionada com alguns dos contaminantes dessa água.

\section{Cuidados com a alimentação}

A ração deve ser elaborada a partir de ingredientes de boa qualidade, adequados à espécie e à fase do ciclo de vida, e oferecida aos animais em quantidades ideais e várias vezes ao dia, para um melhor aproveitamento, evitando-se, assim, excesso de resíduo alimentar. Este favorece não só a proliferação de plantas e animais indesejáveis, como também pode, ao ser degradado por microorganismos, produzir diversas toxinas. 
A alimentação de peixes com dejetos fecais de outras espécies animais, como suínos e aves, contém substâncias tóxicas: amoníaco, nitratos, ácidos orgânicos, dentre outros que contaminam a água e, consequentemente, os peixes, devendo, portanto, ser evitada.

A adubação orgânica, quando utilizada nos viveiros, deve ser feita com esterco curtido, evitando-se com isso a contaminação do peixe. Quando esses cuidados não são tomados, a contaminação destes por coliformes poderá ocorrer, ocasionando no homem uma intoxicação alimentar.

\section{Manejo dos peixes, alevinos e ovos}

Toda cautela é pouca na aquisição de insumos biológicos, de ovos a adultos, devendo as encomendas provirem de aqüicultores que recebam orientação técnica devida ou, até mesmo, registrados junto ao Serviço de Defesa Animal.

As importações indiscriminadas como vem ocorrendo são muito perigosas, podendo introduzir doenças gravíssimas no país. Como exemplo, citam-se a lerneose e a viremia primaveril da carpa, sendo esta última, inclusive, de notificação obrigatória à OIE, e diagnosticada pela primeira vez no Brasil por ALEXANDRINO; RANZANI PAIVA; ROMANO, em 1998.

\section{Cuidado com os viveiros}

O habitat dos peixes, e de modo especial o fundo do viveiro, reúne agentes de doenças contagiosas e a criação de lotes sucessivos sem a devida desinfecção conduz com frequiência a grandes catástrofes. Portanto, a prática de esvaziamento sanitário é a ideal após cada ciclo produtivo. Porém, os interesses comerciais exagerados, frutos da necessidade de se dispor de peixe vivo o ano inteiro, têm tornado impraticável a desinfecção de modo correto.

É aconselhável, após o uso de desinfetantes e de herbicidas, bem como após a calagem, proceder ao enxágüe dos viveiros, retirando-se o excesso da substância utilizada com a prática de esvaziamento. Durante esse período, os viveiros não devem conter peixes.

\section{Limpeza e desinfecção de viveiros e infra-estrutura em piscicultura}

Após terminar o ciclo produtivo ou a despesca, é necessário lavar e desinfetar todos os utensílios de pesca: tarrafas, redes, puçás e outros, bem como os veículos e equipamentos usados nesta atividade, além de não usálos em outros estabelecimentos aqüícolas.

O seguinte procedimento é recomendado para a desinfecção dos viveiros: dissolver em água hidróxido de cálcio (cal hidratada) na proporção de $1500 \mathrm{~kg} / \mathrm{ha}$, ou $500 \mathrm{~kg} /$ ha de óxido de cálcio (cal virgem) e distribuir de maneira homogênea sobre toda a superfície do viveiro, previamente escoado para melhor penetração no solo. $\mathrm{O}$ fundo do viveiro deve ser removido antes de colocar-se a cal. Deixar nessas condições por cerca de duas semanas, dependendo das condições climáticas, ou até que 20 $\mathrm{cm}$ abaixo do fundo do viveiro esteja totalmente seco. Em seguida, o tanque deverá ser preenchido com água no nível adequado tomando-se o cuidado para que o $\mathrm{pH}$ da água fique em torno de 6.8 a 7,0. Caso o pH esteja alcalino, deve-se esvaziar o tanque e enchê-lo quantas vezes for necessário, até o $\mathrm{pH}$ atingir o ideal.

\section{Quarentena}

A quarentena é um método de prevenção necessário para um grande número de afecções de peixes, que são adquiridos no comércio. O período de tempo que os peixes permanecem em isolamento deverá ser de, no mínimo, 30 dias. Nesse período, é possível realizar uma correta vigilância para descartar sinais precoces de enfermidade, além de que servirá para adaptação às novas condições.

Para realizar a quarentena, é necessário que toda propriedade disponha de um viveiro ou mais viveiros para essa finalidade e, antes de iniciar esse processo, os peixes devem passar por um banho curto com cloreto de sódio a 2,5 a 3\% durante 15 a 20 minutos, concentração esta que varia com a espécie.

No primeiro dia de quarentena os peixes não devem ser alimentados e a alimentação deve ser oferecida de modo gradual até se chegar na quantidade ideal. Se nesse período alguma afecção aparecer, deve-se realizar um tratamento baseado no diagnóstico e, após uma semana, assim que os sintomas desaparecerem, finaliza-se a quarentena.

Os tanques para quarentena devem estar situados em local isolado e na parte baixa da propriedade. É recomendada a instalação de pedilúvios na entrada e saída desses tanques.

Deve-se submeter à quarentena ovos, larvas, alevinos, reprodutores e peixes de engorda antes de serem introduzidos na piscicultura, os quais devem estar sob a responsabilidade de um médico veterinário.

Não se deve utilizar produtos químicos de forma irracional nos animais adquiridos enquanto estiverem em 
quarentena. É importante o registro de toda a mortalidade ocorrida durante esse período, bem como o diagnóstico da causa da mortalidade.

\section{Diagnóstico}

A observação dos sintomas e a remessa de peixe doente ou suspeito são fundamentais para o diagnóstico de qualquer doença. Para que o diagnóstico seja elaborado de uma forma efetiva, recomenda-se o envio de peixes vivos que devem ser transportados na própria água do viveiro para um laboratório de patologia.

Todo material enviado ao laboratório deve vir acompanhado de ficha que contenha os dados da propriedade: localização, água, alimentação, utilização dos viveiros, espécies exploradas, procedência dos animais, temperatura média da água, dados sobre mortalidade, quais espécies que estão morrendo, se jovens ou adultos, quantos animais morrem por dia, etc. É interessante que a ficha contenha um breve histórico sobre o quadro clínico observado e se, na unidade piscícola é habitual a realização de quarentena nos exemplares recém adquiridos. Para que este exame seja completo, aconselhamos o uso das fichas de identificação da propriedade e anamnese (ALEXANDRINO et al. 1999a).

O diagnóstico de uma doença em piscicultura fazse associando estes dados obtidos da anamnese com o exame externo, necropsia e colheita de materiais que podem ser para os seguintes exames: bacteriológico, virológico, micológico, histopatológico, hematológico e parasitológico, segundo a suspeita clínica.

Quando o diagnóstico é feito a campo, por não ser possível praticar a coleta assepticamente, os exames ficam limitados. Mas, se a coleta ocorrer em laboratório e de forma asséptica, qualquer um dos exames pode ser realizado.

O diagnóstico clínico e anatomopatológico raramente é específico, porém são recomendados, por permitirem na maior parte das vezes a intervenção do médico veterinário, preconizando terapêutica ou medidas profiláticas de emergência.

O exame macroscópico possibilita a observação das alterações externas que ocorrem na conformação geral dos peixes, pele, olhos, boca, fossas nasais e brânquias.

Para o exame bacteriológico deve-se usar espátula, tesoura e "swab" esterilizados para a colheita de material das partes enfermas, como líquidos de cavidades, lesões superficiais, sangue, amostras de fígado, coração, rim e baço, que deverão ser semeados em meios de cultivo com caldo de carne, caldo de ágar, durante 24 horas à temperatura de $22^{0} \mathrm{C}$ e corados pelo método de Gram. Amostras de tecidos de peixes mortos não devem ser usadas. Este exame deve ser realizado em laboratório especializado, em virtude de a bacteriologia aquática apresentar algumas peculiaridades.

Quando a colheita for realizada para o diagnóstico virológico, deve-se coletar fragmentos de órgãos, como rim e baço, e submetê-los ao congelamento $\left(-20^{\circ} \mathrm{C}\right)$, se o procedimento não puder ser realizado imediatamente. Posteriormente, pode ser submetido às técnicas virológicas de diagnóstico direto e indireto. Este procedimento também deve ser feito à semelhança do bacteriológico, em laboratório especializado.

O diagnóstico das viroses e bacterioses deve ser feito com base no Manual de Diagnósticos de Doenças de Organismos Aquáticos da OIE (1995).

O diagnóstico das micoses é feito utilizando-se material das lesões superficiais que pode ser examinado a fresco. Em casos nos quais há necessidade de se fazer cortes histológicos, utilizam-se técnicas de rotina, para inclusão em parafina, corados por hematoxilina e eosina, safranina, ou ainda técnica de Gomori. O isolamento e o cultivo são realizados geralmente em meio de Sabouraud, adicionando-se agentes antibacterianos. Não se deve coletar amostras de tecidos de peixes mortos.

Peixes inteiros fixados em formol a $10 \%$ também podem ser enviados ao laboratório, desde que neles seja feita uma incisão ventro-longitudinal para que ocorra fixação dos órgãos internos.

O diagnóstico ectoparasitológico, na prática, é exclusivamente direto, utilizando-se material (muco) do tegumento ou de brânquias. Esta metodologia na maior parte das vezes possibilita chegar até o gênero do parasita, o que indicará uma intervenção profilática ou terapêutica. Essa amostra deverá ser observada entre lâmina e lamínula em microscópio óptico comum, deverá ser diluída na própria água onde estão os peixes doentes ou em solução salina. Com esse procedimento podem ser identificado monogenódeos, protozoários e crustáceos. Para a realização deste exame, os peixes não devem ser anestesiados previamente, pois esse procedimento pode mascarar o resultado em razão de os parasitos desprenderem-se do peixe.

O sangue também pode ser coletado para exame laboratorial e serve para realizar esfregaço e hematócrito, quando no campo. Se a coleta ocorrer em laboratório, o procedimento será semelhante ao utilizado para outras espécies animais, onde poderá ser feito hemograma completo e exames bioquímicos. O sangue pode ser coletado do vaso dorsal, próximo à coluna vertebral ou diretamente do coração. É importante lembrar que as hemáceas dos peixes são nucleadas à semelhança das aves. 
Para o exame histopatológico coleta-se material das partes enfermas e aparentemente sadias, fixando-as em formol a $10 \%$, por um período de $24 \mathrm{~h}$ passando para álcool $70^{\circ} \mathrm{Gl}$. Dessa forma, a amostra enviada para o laboratório é submetida às técnicas de rotina para inclusão em parafina e coloração por hematoxilina e eosina. É procedente coletar amostras de peixes doentes, não utilizando peixes mortos para essa finalidade.

\section{PRINCIPAIS DOENÇAS QUE AFETAM OS PEIXES}

No Brasil, o diagnóstico das doenças de peixes não tem sido feito de forma rotineira, o que tem dificultado o conhecimento epidemiológico a respeito delas, associase a este fato a carência de médicos veterinários com conhecimento em ictiopatologia. Passaremos a discorrer sobre as principais doenças e um comentário acerca das que já foram diagnosticadas em nosso país.

A classificação das doenças é a mesma utilizada para outros animais. Podem ser de origem infecciosa tendo como agentes etiológicos: bactérias, vírus, fungos e parasitas ou não infecciosa: doenças metabólicas, nutricionais, neoplásicas, genéticas, provocadas por fatores abióticos, etc.

\section{I - VIROSES}

As principais doenças, de notificação obrigatória, com base no Código Sanitário Internacional para Organismos Aquáticos de 1995, são as viroses. No Brasil, ALEXANDRINO et al. (1998) relataram a ocorrência de viremia primaveril da carpa (VPC) em ciprinídeos (Figura 1). Destacam-se pela importância econômica as seguintes doenças: necrose hematopoiética epizoótica, necrose hematopoiética infecciosa, doença viral do Oncorhynchus masou, viremia primaveril da carpa e septicemia hemorrágica viral.

A prevenção dessas doenças é feita evitando importações indiscriminadas de zonas epidêmicas, e utilizando-se de práticas higiênicas no manejo, como desinfecção de ovos, adquirindo animais de produtores certificados, etc.

Ocorrem, ainda, outras doenças víricas como a doença vírica do "catfish", necrose pancreática infecciosa e a anemia infecciosa do salmão.

Para controlar estas viroses, é necessário sacrificar os sobreviventes, por se tornarem portadores.

\section{II - BACTERIOSES}

Entre as principais doenças bacterianas, que podem afetar os cultivos de peixes, destacam-se pela im-

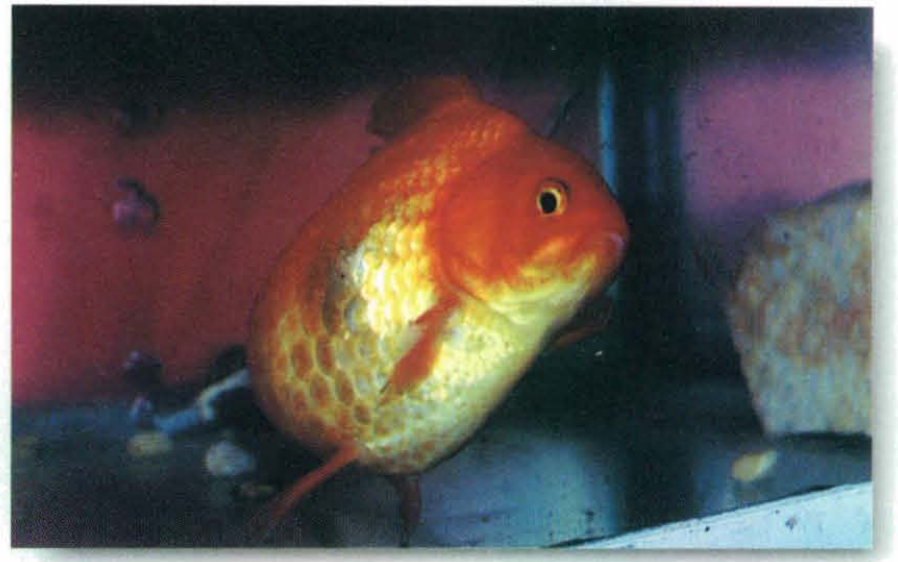

Figura 1 - Kinguio com VPC, observam-se abdômen distendido e áreas hemorrágicas, próximo às nadadeiras peitorais.

portância econômica aquelas que representam grandes perdas econômicas. No Brasil, há poucos relatos de doenças bacterianas. Em 1975, TEIXEIRA FILHO faz o primeiro relato sobre a ocorrência de Pseudomonas punctata em peixes ornamentais. Em 1996, EIRAS et al fizeram um estudo preliminar sobre as bactérias encontradas em pacu (Piaractus mesopotamicus), curimbatá (Prochilodus scrofa) e tambaqui (Colossoma macropomum) criados em confinamento no Estado de São Paulo.

Dentre as principais doenças bacterianas citase: doença bacteriana renal, septicemia entérica do "catfish" ou edwardisielose, pisciriquetsiose, aeromonose, vibriose, furunculose, septicemia hemorrágica, peste vermelha, columnariose, micobacteriose e nocardiose.

A identificação do agente das doenças bacterianas é baseada no isolamento em meios específicos e caracterização mediante testes bioquímicos.

$\mathrm{O}$ controle das doenças bacterianas é feito com o uso de antibioticoterapia, dos quais apenas dois produtos, a oxitetraciclina e as sulfas, são os liberados pela FDA. $\mathrm{Na}$ utilização de antibióticos é necessário aguardar um período de 500 graus/dia de carência para a liberação do produto para consumo. Para chegar ao total de dias, basta dividir 500 pela temperatura média da água dos dias de tratamento.

\section{Doença bacteriana renal}

É uma infecção crônica que ocorre entre os salmonídeos, particularmente do gênero Oncorhynchus (salmões do Pacífico). Esta doença tem sido relatada no norte da América, Japão, oeste europeu e Chile. O agente causal é o Renibacterium salmoninarum, bactéria Gram positiva. 
É uma enfermidade de grande importância econômica para os cultivos de salmonídeos e sua transmissão é vertical, por meio de produtos sexuais.

O diagnóstico é baseado na história clínica, no qual se observam pequeno aumento na mortalidade, alterações macroscópicas do rim e presença de granulomas em cortes histológicos de rim. A comprovação é feita pelo isolamento do $R$. salmoninarum.

\section{Septicemia Entérica do "Catfish"}

É uma doença bacteriana que afeta espécimes de "catfish" dos Estados do Alabama e da Georgia dos EUA. Atualmente foi relatada na Tailândia e, também em espécies de peixes ornamentais. Essa doença é responsável por alta taxa de mortalidade e o agente causal é um bacilo Gram negativo denominado Edwardsiella ictaluri.

O reservatório do E. ictaluri é o intestino do peixe, do qual é eliminado juntamente com as fezes, contaminando o ambiente. A doença ocorre em temperaturas situadas entre 18 e $28^{\circ} \mathrm{C}$. As flutuações sazonais são responsáveis pelo surgimento da doença, sendo que a qualidade da água, a densidade populacional e o estresse são moduladores da virulência do agente.

Em cultivo de truta arco-íris isolou-se Edwardsiella tarda, após um surto com alta taxa de mortalidade. (ALEXANDRINO et al., 1999c. no prelo)

\section{Pisciriquetsiose}

É uma doença causada por Piscirickettsia salmonis que afeta criações de salmão "coho" (Oncorhynchus kisutsch). Foi relatada pela primeira vez no Chile, porém, já foi descrita no Canadá, Irlanda e Noruega. Essa doença acomete outros salmonídeos como a truta arco-

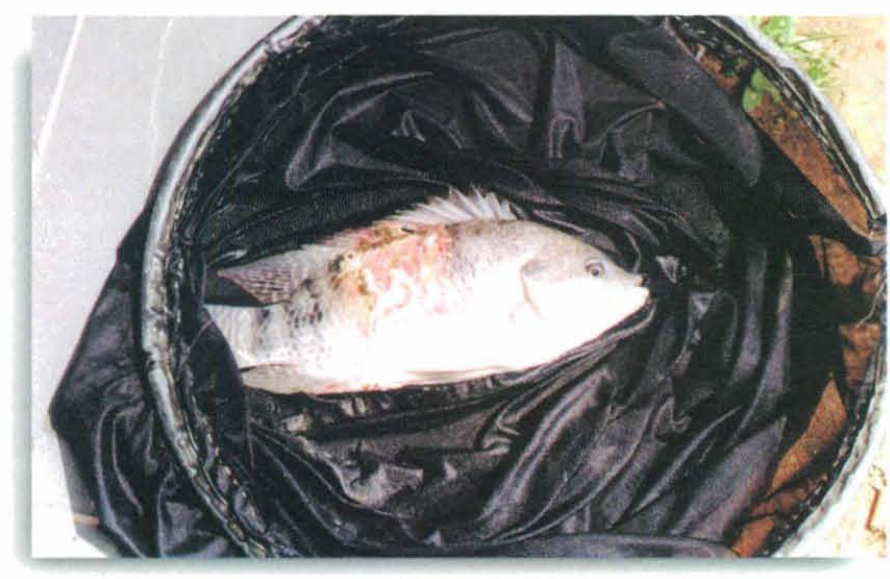

Figura 2 - Aeromonose em tilápia. íris e o Salmo salar. A mortalidade pode variar entre 30 a $90 \%$.

O primeiro sinal clínico dessa doença é o surgimento de pequenas lesões na pele e úlceras hemorrágicas. O peixe infectado torna-se escuro e letárgico. As alterações observadas são palidez das brânquias, peritonite, ascite, baço aumentado e fígado com grandes áreas de necrose.

Como medida preventiva, recomenda-se desinfetar os ovos.

\section{Doenças causadas por aeromonas e víbrio}

$\mathrm{Na}$ família Vibrionacea encontra-se os gêneros Aeromonas e Víbrio, que são bacilos Gram negativos e anaeróbios facultativos. Podem ser encontradas duas espécies de Aeromonas patogênicas para os peixes: $A$. hydrophila e A. punctata.

A A. hydrophila tem seu habitat natural na água doce, rica em matéria orgânica, podendo fazer parte da flora intestinal natural do peixe. Este agente está sempre associado a doenças como a septicemia hemorrágica vírica, a viremia primaveral da carpa e, de um modo geral, ao estresse. Pode, ainda, estar associada a enfermidades de rãs e de mamíferos, incluindo-se o homem.

Os peixes apresentam inicialmente lesões superficiais (Figura 2) e posteriormente ascite, escurecimento da pele e extensas hemorragias na superfície do corpo e na base das nadadeiras. Ầ necropsia, observam-se órgãos internos congestos e as vísceras hemorrágicas. O rim e o baço estão aumentados. Histopatologicamente é difícil distinguir da infecção por Pseudomonas. Em ambos os casos, o tecido hematopoiético esplênico e renal encontram-se atrofiados e com necrose; o pâncreas, músculo cardíaco e fígado mostram-se com focos necróticos e a mucosa intestinal desprendendo-se facilmente.

O isolamento da A. hydrophila é feito a partir de cultura em meios comuns de rim ou sangue dos peixes enfermos.

Como medida preventiva deve-se manter os animais em boas condições de saúde e proceder a limpeza periódica dos viveiros, pois o lodo do fundo é um excelente meio para reprodução dessa bactéria.

\section{Furunculose}

A Aeromonas salmonicida é o principal responsável pela furunculose, conhecida como enfermidade epidérmica dos salmonídeos, ocorrendo em qualquer ida- 
de. Pode, também, provocar enfermidades infecciosas em outros peixes. A enfermidade é conseqüência da introdução de peixes portadores latentes aos sadios do plantel. Os fatores desencadeantes podem ser a elevação da temperatura, a concentração baixa de oxigênio e a alta densidade. Entre os salmonídeos, a truta arcoíris é a mais resistente e o salmão do Atlântico o mais sensível.

A furunculose faz parte do grupo das enfermidades septicêmicas produzidas por bactérias Gram negativas. Seu quadro clínico e sua evolução dependem da virulência da cepa infectante, da idade dos peixes e da temperatura da água. A furunculose pode manifestar-se de várias formas. A subaguda manifesta-se por abcesso contendo material purulento hemorrágico, onde as bactérias podem ser encontradas e observadas sob microscopia de luz quando coradas pelo método de Gram. Podese, ainda, encontrar o agente causal em órgãos internos, como o rim e baço, e no sangue. A enfermidade aguda pode ocorrer sem sintomas externos, sendo freqüente as inflamações e hemorragias de órgãos internos. Para evitar a doença é recomendado a introdução de peixes que se conheça a procedência.

\section{Septicemia hemorrágica}

A Pseudomonas fluorescens causa septicemia hemorrágica. É encontrada no solo e na água, podendo, muitas vezes, ser isolada de peixes em decomposição e de alimentos deteriorados. Este microorganismo cresce em meios nutritivos comuns. De modo geral, pode acometer todos os peixes.

Clinicamente esta doença não se distingue da causada por Aeromonas e está intimamente relacionada com estresse ambiental, em especial com altas temperaturas. A septicemia pode ser aguda ou crônica. Os sinais mais característicos são lesões hemorrágicas sobre a pele e morte rápida dos peixes doentes. Nos casos crônicos, ocorre peritonite fibrinosa hemorrágica.

Como medida preventiva, é recomendado o aprimoramento nas condições ambientais e a terapia medicamentosa, quando for recomendada, só dever ser feita quando a causa tiver sido removida, principalmente quando tratar-se de água rica em matéria orgânica.

\section{Peste vermelha}

O Víbrio anguillarum é o agente etiológico da peste vermelha das enguias, e é também conhecida como vibriose, podendo acometer outros peixes marinhos. É um bacilo Gram negativo e pode ser cultivado em meios comuns. O período de incubação está diretamente relacionado com a temperatura da água, com a virulência da cepa e com o grau de estresse a que está submetido o peixe. A mortalidade pode alcançar até $50 \%$ da população, principalmente em peixes jovens. As lesões observadas são necrose cutânea superficial, principalmente na região da cabeça, estendendo-se até a musculatura, que se apresenta inflamada, e hemorragias petequiais na pele. No coração, observam-se hemorragia e focos bacterianos. A principal característica das lesões internas é o aumento de volume e liquefação do baço e rim. As brânquias mostram-se pálidas. Se a evolução da doença é do tipo crônico, as lesões da pele podem evoluir para um granuloma, as brânquias permanecem pálidas e a sucessão de hemorragias na cavidade abdominal culmina em aderências fibrinosas entre as vísceras. Observa-se também opacidade da córnea, que pode evoluir para ulceração e perda do conteúdo da cavidade orbitária. Histopatologicamente, observam-se miopatia cardíaca, necrose renal e esplênica e edema peritoneal nos casos super agudos. No caso agudo, as lesões cardíacas são menos graves e caracterizam-se por lesões de pele e musculatura. No fígado, ocorre necrose focal; no rim e baço, necrose hematopoiética.

O controle desta doença é feito com o uso de antibióticos.

\section{Columnariose}

É uma doença causada pelo Flavobacterium columnaris, que afeta principalemente os salmonídeos, difundida em escala mundial entre os peixes de água doce, incluindo os ornamentais.

A columnariose tem início como uma infecção externa, com lesões na pele, nadadeira e brânquias que, segundo a espécie, podem provocar extensa necrose, com presença secundária de fungos. O material coletado dessa região exibe, em geral, disposição típica das bactérias formando coluna. $\mathrm{O}$ quadro patológico caracteriza-se pela inflamação e, muitas vezes, espessamento das lamelas branquiais, que às vezes chegam a fusionar-se; os opérculos podem apresentar-se abertos pela inflamação. As brânquias têm, no início, uma coloração vermelho escura e, posteriormente, tornam-se pálidas e viscosas, podendo ainda as bactérias provocar um quadro septicêmico.

Preventivamente é recomendado melhora nas condições gerais do meio, principalmente no que se refere ao teor de oxigênio dissolvido na água, controlando a matéria orgânica e diminuindo a temperatura. 


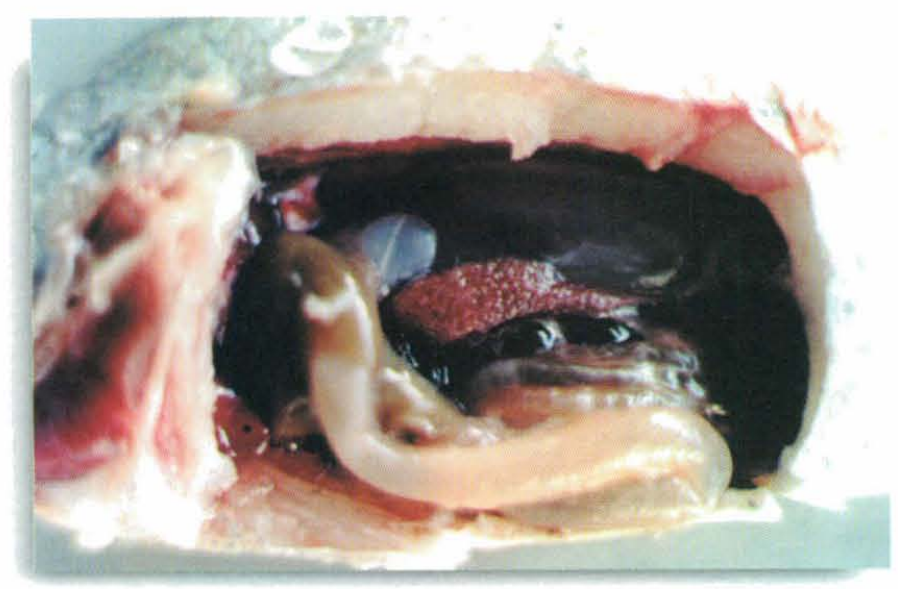

Figura 3 - Micobacteriose em tilápia. (Observar pontos brancos sobre o baço).

O tratamento com antibióticos nem sempre é satisfatório, em virtude de os peixes não estarem se alimentando. Neste caso, o tratamento pode ser feito por meio de banhos.

\section{Micobacteriose}

As micobacterioses são doenças causadas por micobactérias. São bacilos retos, ácido-álcool-resistentes (ZN positivo). Ocorrem três espécies: Mycobacterium marinum, $M$. fortuitum e $M$. chelonei.

O M. marinum tem seu habitat desconhecido, porém o peixe portador do bacilo é considerado responsável pelas infecções nos aquários. Seu cultivo é feito em temperaturas entre 25 e $35^{\circ} \mathrm{C}$, ou superior, crescendo em meios comuns para o isolamento de micobactérias.

Os sintomas da doença variam muito, ocorrendo desde a perda de peso, necroses e cistos em órgãos internos, até inflamações cutâneas. Quando a doença é aguda, ocorre o enfraquecimento dos animais ao extremo e, com freqüência, estes são vistos na superfície da água; em quase todos os órgãos podem ser isolados bacilos ácido-resistentes. Quando a doença se transforma em crônica, as bactérias são envolvidas por um processo granulomatoso, formando focos cinzentos ou esbranquiçados no fígado e rim. Nestes casos, a qualquer momento pode produzir-se reativação das bactérias e, assim, surgem casos agudos da enfermidade. Em casos crônicos, podem ser observados os granulomas em que são encontrados os bacilos ZN-positivos.

A doença é típica de manejo inadequado (falta de luz, vitaminas, etc.) A prevenção consiste em melhorar as condições de vida e, nos casos graves, na eliminação dos peixes infectados.

O Mycobacterium fortuitum tem distribuição mundial e tem sido isolado de várias espécies de pei- xes, principalmente daquelas que vivem em água quente. É também encontrado em ciprinídeos e salmonídeos.

No Brasil, o único trabalho experimental existente sobre a ação do Mycobacterium marinum em tilápia do Nilo é de ISHIKAWA (1998), (Figura 3).

Como medida preventiva, de uma modo geral, são recomendados a desinfecção de ovos, aprimoramento nas condições ambientais no que se refere ao teor de oxigênio dissolvido na água, controle de matéria orgânica, evitar super população, introdução de peixes de fontes não idôneas, ou melhor, evitar toda a situação que leve ao estresse, o que torna os peixes susceptíveis às doenças infecto-contagiosas e parasitárias.

\section{III - MICOSES}

\section{Saprolegniose}

A saprolegniose é a dermatomicose mais conhecida, ocorrendo nos peixes de água doce em qualquer época do ano (Figura 4). O fungo Saprolegnia afeta os ovos de salmonídeos em incubação, sendo o início da infecção nos ovos mortos, estendendo-se posteriormente aos ovos sãos. Pode afetar, também, as brânquias e a pele, acometendo principalmente animais debilitados, após o manuseio, em altas densidades, quando ocorrem alterações bruscas de temperatura e modificações das condições físico-químicas da água, principalmente relacionadas ao baixo teor de oxigênio dissolvido na água, e normalmente atuam em infecções secundárias.

O controle dessa doença é feito mantendo-se os animais em condições adequadas de cultivo, alimenta-

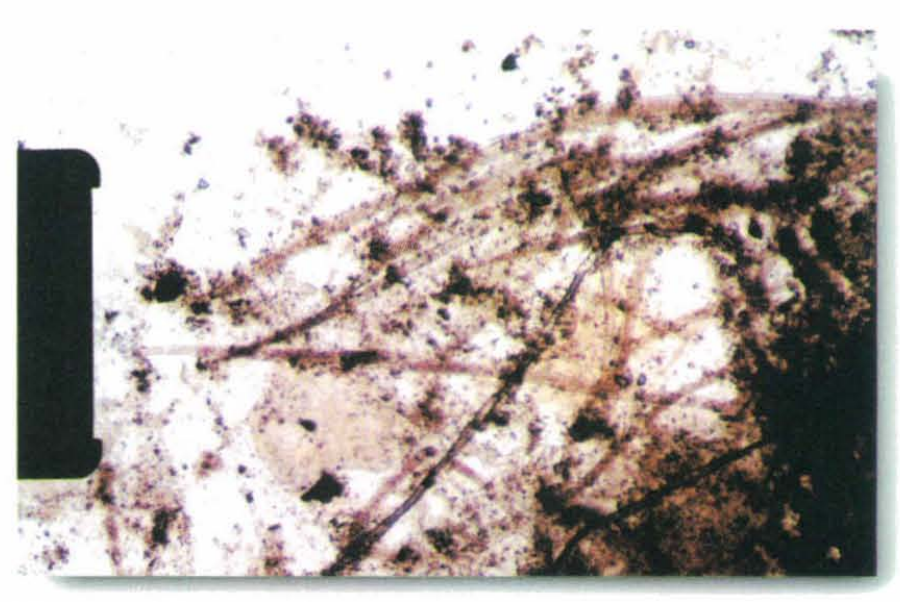

Figura 4 - Esfregaço de muco de tegumento, mostrando hifas de Saprolegnia. 
ção, mantendo-se a água com boa qualidade e evitandose superpopulação.

Essa doença é muito comum em pacu, tambaqui, piauçu após manuseio, transporte e outras condições que promovam retirada de escamas e tecidos epiteliais.

\section{Branquiomicose}

É causada pelo fungo do gênero Branchiomyces spp e acomete principalmente os ciprinídeos, causando necrose das brânquias devido ao crescimento dos fungos dentro dos vasos sangüíneos.

Os sinais apresentados são de descoloração, apresentando as brânquias coloração castanho-amarelada e o aparecimento de hifas fúngicas, visíveis às vezes macroscopicamente.

O controle dessa doença é feito mantendo-se os peixes em condições adequadas de higiene.

\section{IV - PARASITOSES}

Os parasitos que podem afetar os peixes são muito abundantes e incluem membros de diferentes grupos zoológicos. Assim, pode ocorrer parasitismo por protozoários, helmintos, crustáceos e hirudíneos. Todavia, a presença desses parasitos nos peixes cultivados dependerá, em grande parte, das condições do cultivo, da procedência dos peixes e do ciclo vital dos parasitos.

A literatura brasileira é precária quanto à citação de doenças parasitárias. Em 1995, foi feito apenas um levantamento de possíveis agentes etiológicos de parasitoses nas Estações Experimentais do Instituto de Pesca, no Estado de São Paulo (EIRAS et al. 1995).

As infestações parasitárias dos peixes aumentam, principalmente quando os peixes são mantidos em densidade elevada e quando as condições higiênico sanitárias deixam a desejar. Dessa forma os animais ficam sujeitos ao estresse tornando-os debilitados e, portanto, susceptíveis às doenças que podem vir acompanhadas de elevada mortalidade, sobretudo no caso de parasitos de ciclo direto, como acontece com certos protozoários ou com os monogenódeos. Por outro lado, os parasitos que não produzem epizootia em peixes podem ser, contudo, promotores de enfermidades importantes, já que atuam debilitando o hospedeiro e facilitando a introdução de infecções, seja como vetores de outros patógenos, seja favorecendo infecções secundárias.

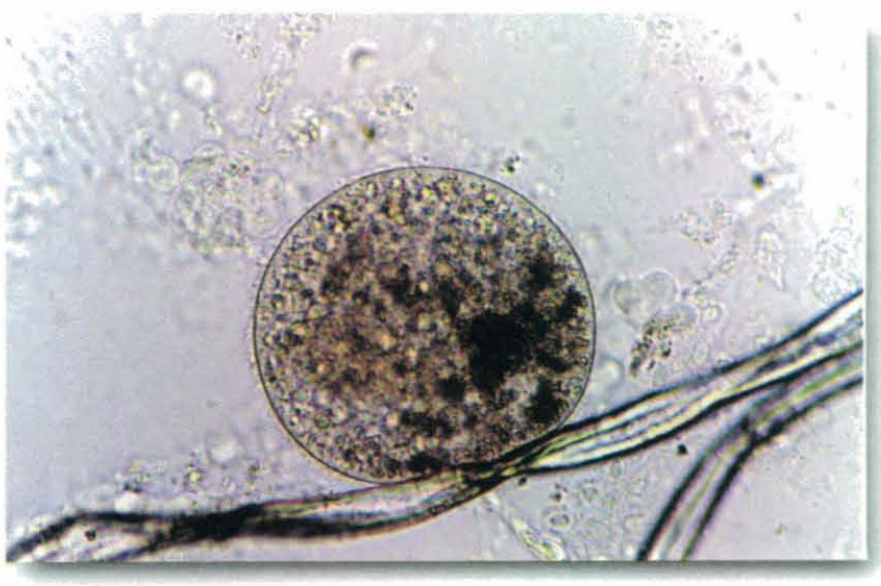

Figura 5 - Ichthyophthirius multifiliis em esfregaços de brânquias de pacu.

Dos fatores ambientais, a temperatura pode ser considerada o mais importante. Em geral, as doenças parasitárias ocorrem no inverno, principalmente em piauçus, pacus, tambaquis, matrinxãs, espécies do Pantanal brasileiro e da Bacia Amazônica. Estes peixes, por não estarem adaptados às condições climáticas do sudeste $\mathrm{e}$ sul do país, onde as temperaturas são inferiores às suas de origem, tornam-se estressados e vulneráveis a parasitose. Dentre outros fatores que podem influenciar o parasitismo destacam-se à concentração de oxigênio e a iluminação.

\section{Doenças causadas por protozoários}

\section{Ictiofitiriose}

O Ichthyophthirius multifiliis conhecido vulgarmente como "ictio" é o agente da ictiofitiriose, também conhecida como doença dos pontos brancos. O agente é cosmopolita e, sem dúvida, a ictiofitiriose é uma das principais afecções dos peixes de água doce, de regiões tropicais ou temperadas. No Brasil, sua ocorrência tem sido freqüente nos peixes de regiões quentes, quando cultivados em regiões mais frias e tem causado alta taxa de mortalidade. O parasito pode ser encontrado em qualquer parte do corpo, mas infesta normalmente a epiderme, nadadeiras e brânquias. Quando a infestação é muito alta, ocorre, inclusive, na córnea e nos epitélios da boca e do esôfago. Os peixes afetados adquirem uma coloração acinzentada e morrem, em parte por falência na osmorregulação.

O diagnóstico é feito ao microscópio, utilizando-se raspados de pele e de brânquias, a fresco, onde se observa o parasito, rodeado por cílios e com o núcleo grande em ferradura (Figura 5).

A prevenção desta enfermidade baseia-se essencialmente em manter os peixes de maneira confortável. 


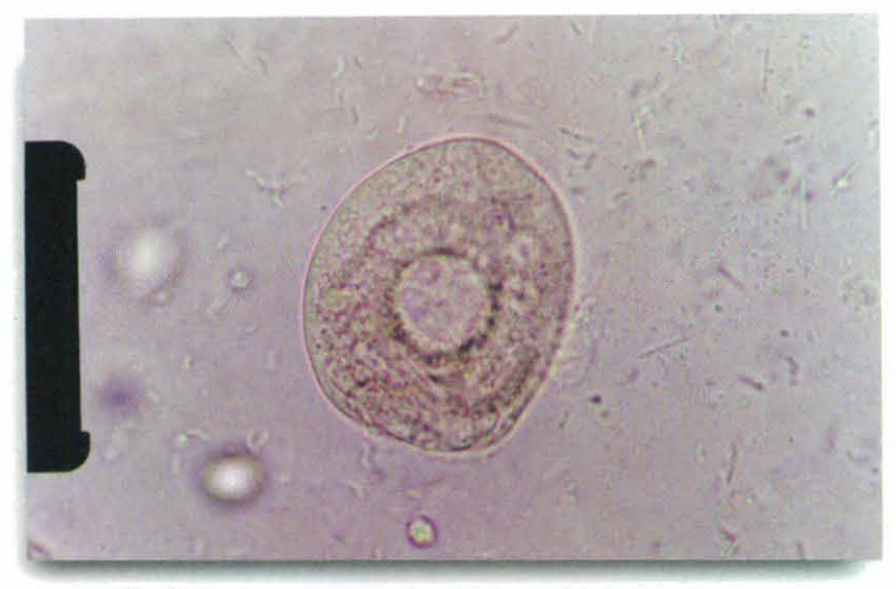

Figura 6 - Esfregaço de pele de tilápia - Chilodonella sp.

Portanto, os animais devem estar bem nutridos, em condições sanitárias desejáveis e realizar quarentena nos animais recém adquiridos. Deve-se evitar a superpopulação e principalmente não expor os animais a quedas bruscas de temperatura.

\section{Criptocarionose}

Também é chamada de enfermidade dos pontos brancos, afeta os peixes tropicais em ambientes marinhos e assemelha-se muito com a ictiofitiriose. O agente etiológico é o Cryptocaryon irritans.

\section{Chilodonelose}

A Chilodonella é muito importante por acometer muitas espécies de peixes de valor comercial, tanto em ambiente natural quanto em tanques de cultivo e aquários. Este parasito alimenta-se de células epiteliais, sendo muito comum sua ocorrência em baixas temperaturas. Nos ciprinídeos, salmonídeos e ictalurídeos, esse agente pode produzir congestão branquial e morte.

O primeiro relato da ocorrência dessa moléstia parasitária no Brasil foi em tilápias de uma propriedade particular em Minas Gerais (Figura 6). Os animais apresentavam infestação maciça, eriçamento e perda de escamas, deixando grandes áreas de pele descobertas e congestão nas brânquias. A taxa de mortalidade no lote foi alta (ALEXANDRINO et al., 1999a, no prelo).

\section{Brooknelose}

O gênero Brooklynella é o protozoário equivalente da Chilodonella, afetando brânquias dos peixes marinhos, em aquário.

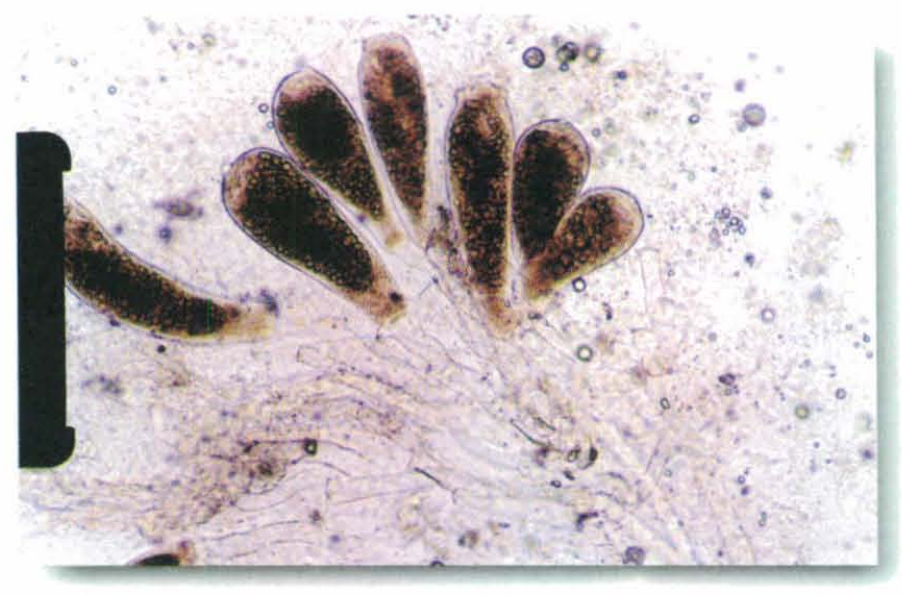

Figura 7 - Esfregaço de muco de tegumento - Epistylis sp.

\section{Epistiliose}

O Epistylis sp ocorre freqüentemente em peixes de água doce e podem ser muito patogênico quando encontra um hospedeiro debilitado. Esse agente foi encontrado em pacus que apresentavam lesões de pele, devido a uma alta infestação de Lernaea cyprinacea (Figura 7).

Esse parasito tem maior ocorrência em pacus, tambaquis e outras espécies, principalmente quando estes se apresentam infestados por Lernaea cyprinacea ou outra parasitose. Na superfície dos ovos dos peixes podem fixar-se o Epistylis e outros peritricos pedunculados, como o Carchesium, Vorticella. Para os cultivos de salmonídeos, esses parasitos podem trazer grandes prejuízos.

Preventivamente, recomenda-se um bom manejo no plantel, evitando-se traumatismos, parasitoses e alta densidade populacional, por ser este agente um oportunista.

\section{Tricodiniose}

É uma enfermidade importante causada pelos gêneros Tripartiella, Trichodinella e Trichodina. Estes parasitos podem produzir epizootíase em peixes marinhos e de água doce.

Os tricodinídeos fixam-se nos peixes pelo extremo oposto à boca e adquirem uma forma de aspirador. Quando a infestação é alta, os parasitos são vistos por toda a superfície corpórea do peixe, provocando reação inflamatória, não só no tegumento como também na musculatura.

Para evitar essa doença, recomenda-se o uso de água de boa qualidade, tendo-se o cuidado de controlar o conteúdo de matéria orgânica. 


\section{Henenguyose}

Doença provocada por agentes do gênero Hennenguya, amplamente distribuída, principalmente em peixes de água doce (Figura 8). Apresenta-se como múltiplos cistos brancos nas brânquias e músculos, de aproximadamente $2 \mathrm{~mm}$. Esses cistos quando rompem eliminam esporos infectantes na água. Estes esporos medem cerca de 40mm e infestam novamente os peixes (CORDEIRO et al. 1983/84; ALEXANDRINO et al. 1995, BRUNO; POPPE,1996 ).

\section{Amilodiniose}

Enfermidade causada pelo Amyloodinium sp, que é um flagelado responsável por epizootias fatais em peixes de aquários marinhos tropicais ou em cultivos de peixes marinhos. Este agente patogênico invade a pele e as brânquias e alimenta-se de células epiteliais.

\section{Oodiniose}

Enfermidade causada pelo Oodinium $s p$, que é outro flagelado que acomete peixes tropicais e subtropicais de água doce, causando epizootia responsável por alta mortalidade devido à ocorrência de obstrução branquial e lesão cutânea.

\section{Criptobiose}

Outro flagelado responsável por grandes mortalidades de truta arco-íris é a Cryptobia sp, parasito freqüentemente encontrado no sangue, que tem sido isolado também de pele e brânquias. Quando a infestação é alta, pode causar obstrução branquial com exsudato e secreção excessiva de muco sobre a pele.

Semelhante à Cryptobia, o Trypanosoma é também um protozoário sangüíneo e flagelado. É transmitido ao peixe pelo sanguessugas e não se conhecem os efeitos produzidos por ele.

\section{Ictiobodose (Costíase)}

O Ichthyobodo necator (Costia necatrix) é um parasito obrigatório responsável por grande perda econômica. De distribuição cosmopolita, pode afetar todos os peixes de água doce, inclusive os cultivos de salmonídeos. Este protozoário adere na pele dos peixes, causando necrose das células epiteliais e hemorragias. Frequientemente afeta as brânquias, ali provocando uma congestão aguda, seguida de morte (Figura 9). Quando

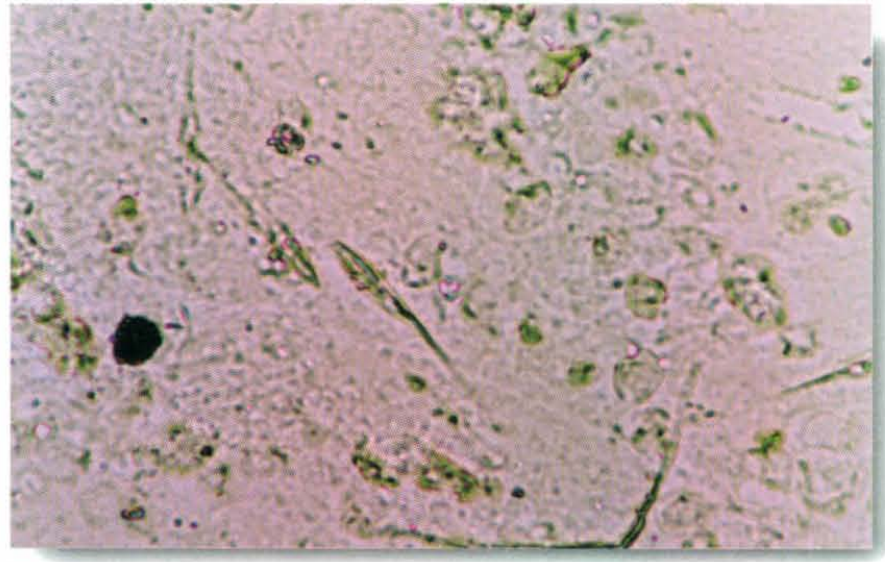

Figura 8 - Esfregaço de muco de tegumento de brânquias - Henneguya $\mathrm{sp}$.

a infestação é intensa, produz irritação da pele com hipersecreção de muco dando à pele uma impressão de revestimento acinzentado. Os peixes com alta infestação batem-se contra a parede e perdem escamas, abrindo caminho para infecções secundárias por bactérias e fungos. Essa doença já foi diagnosticada em um plantel de pacus jovens e, de modo geral, os alevinos são os mais susceptíveis (ALEXANDRINO; PINTO, 1998).

\section{Mixobolose}

O Myxobollus cerebralis é um dos mixosporídeos mais importantes para os salmonídeos acometendo a cartilagem cranial. Esta doença atualmente está difundida na maioria dos países que têm cultivo de truta e sua disseminação é feita por trutas vivas, congeladas, ou até mesmo pela água que acompanha os ovos, tendo sido responsável por grande perda econômica.

$\mathrm{Na}$ fase larvária, os parasitos alimentam-se de cartilagem cefálica, principalmente aquela que cobre a cápsula auditiva, sendo esta a causa de os alevinos apresentarem dificuldade de equilíbrio e natação em espiral. Poste-

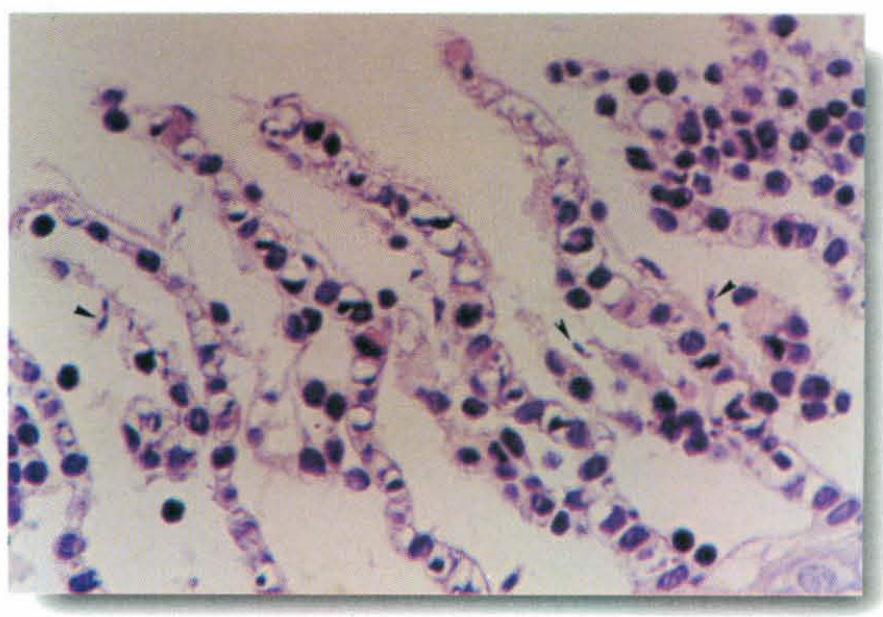

Figura9 - Corte histológico de brânquias - Icthyobodo necator. HE. 400x. 
riormente, os parasitos acometem a ráquis, o que dá origem a deformações e escurecimento do extremo corporal.

A mortalidade é ao redor de $10 \%$ entre os alevinos. Os peixes adultos podem ser acometidos pelo Myxobollus cerebralis, porém, não necessariamente morrem, por possuírem pequena quantidade de cartilagem. No entanto, as larvas e os esporos encapsulam-se nas cavidades ósseas, e esses peixes podem tornar-se portadores assintomáticos e prováveis responsáveis pela disseminação da doença.

Ao que tudo indica, as trutas arco-íris com mais de seis meses são resistentes à enfermidade. Portanto, recomenda-se profilaticamente que os alevinos até essa idade sejam criados em tanques de alvenaria para que depois, se for o caso, sejam colocados em tanques de terra, evitando-se assim que eventuais esporos em maturação no lodo do fundo dos viveiros os infeste.

No Brasil, até o momento não há relato dessa doença. É observada a presença de Myxobollus spp. em esfregaços de pele e de brânquias de piauçu, pintado, etc. feitos rotineiramente.

\section{Ceratomixiose}

Outro mixosporídeo importante principalmente para os salmonídeos jovens da natureza e de cultivos é a $\mathrm{Ce}$ ratomyxa shasta. Esse parasito multiplica-se e invade os tecidos do hospedeiro, formando nódulos no intestino, fígado, rim, baço e músculo. O sintoma mais característico é a ascite.

É recomendado como medida profilática a não importação de ovos e peixes vivos de regiões contaminadas, uma vez que não há tratamento curativo.

\section{Outros Protozoários}

Outros protozoários que podem ocorrer nos peixes são os microsporídeos do gênero Glugea, que produzem

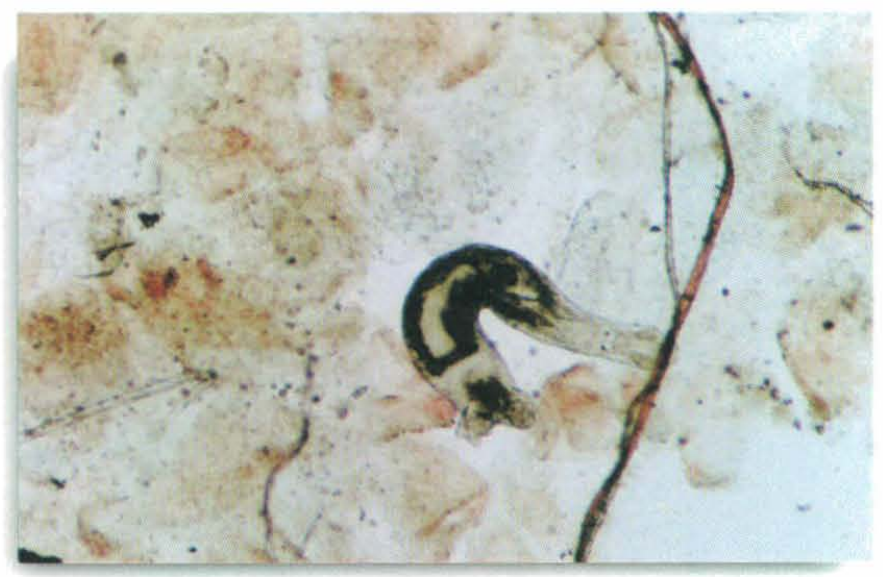

Figura 10 - Esfregaço de brânquias de pacu - Dactylogirus sp. também epizootia, afetando principalmente o fígado de peixes da natureza. Os coccídeos são parasitos de células intestinais e pertencem ao grupo Sporozoa.

Muitas espécies de Eimeria têm sido isoladas do trato digestivo de peixes de água doce e marinha; assim, a Eimeria subepithelialis é responsável pela coccidiose nodular em carpas. Os animais com eimeriose apresentam baixo rendimento, edemaciação e, raras vezes, morrem. Histologicamente, observam-se as esporogônias na submucosa, alcançando o tecido conjuntivo até a superfície da luz intestinal e formando nódulos brancos de 1 a $3 \mathrm{~mm}$ de diâmetro.

Ocorre ainda, em carpas de 1 ano de idade, uma enterite grave causada pela Eimeria carpelli. Todos os estádios de desenvolvimento do parasito ocorrem nas células epiteliais intestinais, produzindo úlceras, e acúmulo de detritos celulares e esporos na luz intestinal, que dão ao muco uma coloração amarelada. Os peixes acometidos sofrem uma edemaciação prévia antes da morte e aqueles que não morrem tornam-se portadores latentes da doença. A profilaxia de eimeriose é feita desinfetando-se o viveiro adequadamente antes do início de um novo ciclo produtivo.

\section{HELMINTOSES MONOGENEA: ectoparasitas de brânquias e de pele}

\section{Girodactilidose e Dactilogiridose}

São ectoparasitas da pele, brânquias e nadadeiras. Os girodactilídeos são agentes importantes nos cultivos de água doce e salgada, afetando principalmente o tegumento dos peixes. Essa parasitose tem o seu aparecimento quando o cultivo está em condições inadequadas, como por exemplo: alta densidade, excesso de matéria orgânica, baixo teor de oxigênio dissolvido, etc. Nessas infestações podem ocorrer, simultaneamente, outras ectoparasitoses por protozoários.

Os dactilogirídeos são cosmopolitas e freqüentemente parasitam brânquias. Fazem parte desse grupo os gêneros Dactylogyrus, Actinocleidus, Ancyrocephalus e Haliotrema.

Os sinais clínicos dessas doenças são muco em excesso, úlceras na pele e lesões nas brânquias. Os dactilogirídeos são bastante danosos para o cultivo de ciprinídeos, tilápias, e espécies brasileiras, como o pacu, tambaqui, piauçu, híbrido tambacu, etc., afetando e matando principalmente os alevinos (ALEXANDRINO et al, 1995) (Figura 10). As monogenoses são afecções cutâneo-branquiais pruriginosas e deteriorantes. Os alevinos e os juvenis são mais susceptíveis e a doença manifesta-se por meio de movimentos esporádicos, desliza- 


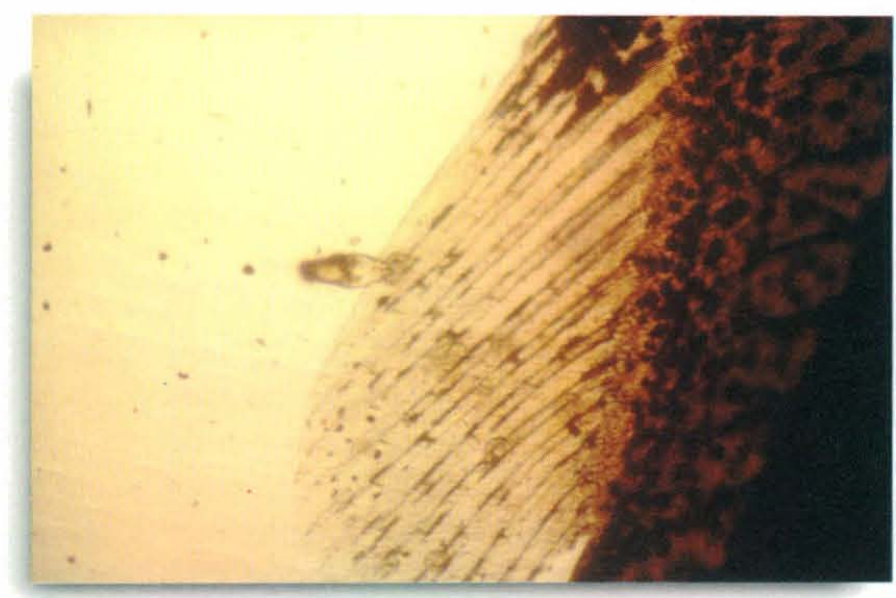

Figura 11 - Esfregaço de pele de tilápia - Gyrodactilus sp.

mentos sobre os apoios disponíveis e alterações respiratórias, no caso de afecção branquial. No caso da girodactilose, é observada uma descamação epidérmica e necrose de tecidos, que podem, inclusive, ulcerar (Figura 11). Esse sintoma demonstra a irritação causada pelo parasito e pelo prurido. Os peixes podem, ainda, apresentar queratite e cegueira, sendo esta resultado da implantação direta do parasito no olho ou por seu contato imediato.

\section{Helmintose por trematodeos Digenea}

São endoparasitos com ciclo evolutivo que necessitam de pelo menos um hospedeiro intermediário. Os estádios de larvas e adultos podem ser encontrados nos peixes, sendo que a larva encontra-se freqüentemente encistada (Figura 12). Pertence à classe Digenea as famílias Sanguinicolidae, Bucephalidae e Allocreadiidae que são digenéticos hermafroditas. Os peixes podem ser infestados por parasitos Digenea que são ovíparos. Geralmente, os ovos eclodem fora do hospedeiro, liberando uma larva ciliada que nada para encontrar um molusco, que é o primeiro hospedeiro intermediário. Neste hospedeiro, o parasito sofre uma fase de reprodução assexuada que termina com a liberação das cercárias. Estas nadam livremente até 24 horas para encontrar o segundo hospedeiro; se dentro deste tempo este não for encontrado, elas morrem. Quando encontram uma determinada espécie de peixe, penetram e tornam-se adultas; em outras, o peixe atua como hospedeiro intermediário e as cercárias se encistam para formar o estádio de metacercárias, podendo viver neste estádio muitos anos. O ciclo se completa em um outro peixe, uma ave ou mamífero, se porventura ingerirem esses animais infestados com metacercárias.

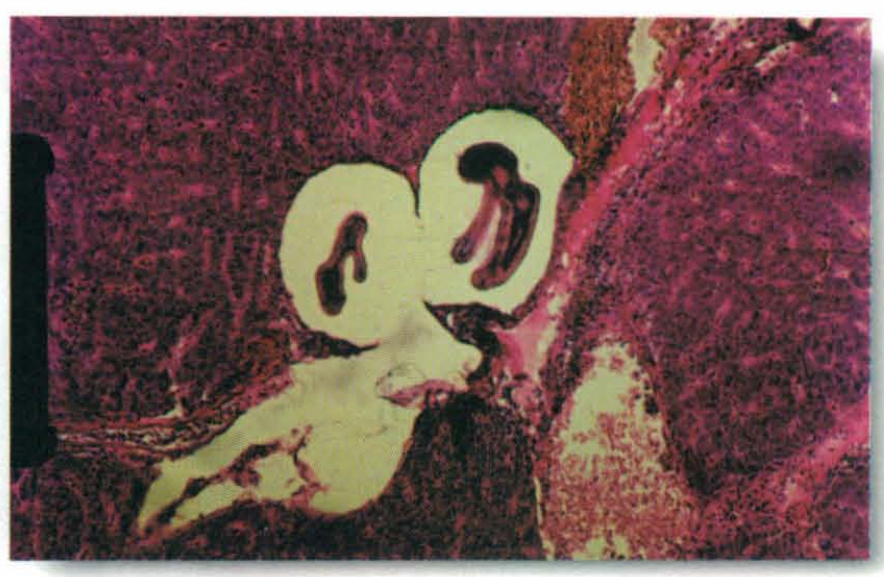

Figura 12 - Cisto de tremátoda digenea (Phagicola longa) em fígado de tainha.

Pode, ainda, ocorrer um terceiro tipo de ciclo evolutivo, caso as cercárias se encistem em um invertebrado, hospedeiro secundário. O ciclo completa-se quando o invertebrado infestado é ingerido por um hospedeiro final adequado.

\section{Metacercariose}

Enfermidade causada por metacercárias dos Digenea que se encistam na pele, músculo, nadadeiras de peixes de água doce e marinha (Figura 13). Ao redor do cisto, observam-se depósitos de melanina, dando um aspecto enegrecido aos cistos (Figura 14). Essa enfermidade é chamada de "blackspot", doença dos pontos negros. Os peixes quando estão altamente infestados, apresentam um aspecto desagradável, não crescem e perdem valor comercial. As cercárias do Posthodiplostomum cuticola localizam-se geralmente na pele dos ciprinídeos e foram diagnosticadas em tambacus jovens por ALEXANDRINO et al. (1996a). Nesses animais,

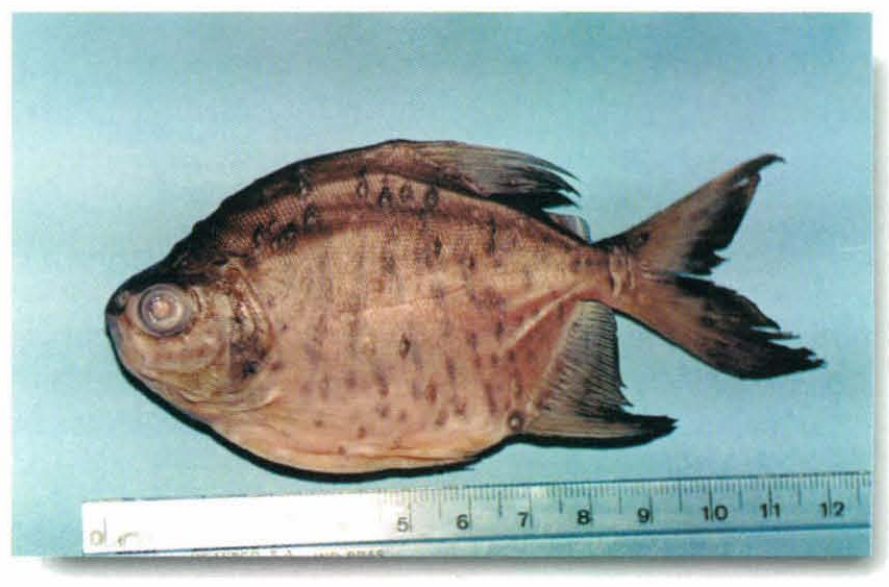

Figura 13 - Pacu com metacercariose - Posthodiplostomum cuticola. 


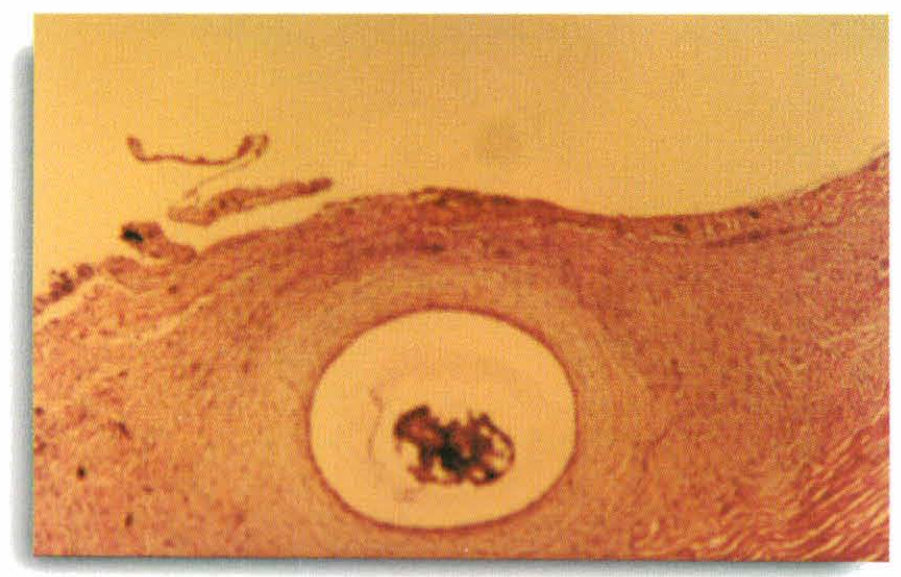

Figura 14 - Cisto de metacercária em pacu em corte histológico. HE 200x.

foram observados pontos pretos disseminados por todo o corpo e nadadeiras e atraso no crescimento, muito provavelmente em função de estarem submetidos a condições de estresse, provocando-lhes anorexia e inapetência. A profilaxia nesse caso é fundamental e é feita mediante a eliminação dos moluscos, hospedeiros intermediários, porque não existe tratamento eficaz contra essa doença.

\section{Doenças causadas por nematóides}

Os helmintos são parasitos freqüentes da cavidade abdominal e das vísceras dos peixes, encontrando-se em sua grande maioria no estágio de larva, onde o peixe atua como hospedeiro intermediário no ciclo evolutivo. Esses helmintos podem afetar diferentes órgãos e seus efeitos são mais freqüentes e significativos em peixes de água doce para fins de cultivo ou esportivo. As larvas dos nematódeos ascarídeos dos gêneros: Contracaecum, Thynnarcaris e Anisakis são encontradas normalmente na cavidade abdominal de muitos peixes marinhos. O Contracaecum é responsável pela morte de alevinos de arenques mantidos em aquário. $\mathrm{O}$ primeiro hospedeiro intermediário deste parasita são crustáceos, e o hospedeiro definitivo pode ser um peixe, ave ou mamífero marinho. As larvas de Anisakis podem produzir cistos nos músculos do hospedeiro, dando um aspecto repugnante para o consumidor e, se é ingerido vivo pelo homem no consumo de peixes crus ou mal cozidos, podem originar um granuloma eosinofílico gastrointestinal, de interesse médico. Alguns gêneros de ascarídeos não só podem passar de um peixe para outro e disseminar-se entre os peixes nos cultivos de água doce ou marinha, como também podem ser transmitidos a outros peixes pela alimentação, quando restos de peixes marinhos infes- tados são oferecidos como alimento. Como medida profilática preconiza-se o consumo de peixes bem cozidos, uma vez que o congelamento a $-20^{\circ} \mathrm{C}$ não tem sido satisfatório. Recentemente, foi relatado que, mesmo o peixe estando cozido, a larva é passível de provocar reações alérgicas no ser humano.

As larvas de Eustrongylides podem ser encontradas encistadas no interior da cavidade abdominal e musculatura de muitas espécies de peixes de água doce de todo o mundo. Seu aspecto é repugnante em função do tamanho da larva, de cerca de $10 \mathrm{~cm}$ de comprimento e por sua coloração vermelha. O hospedeiro intermediário é provavelmente um oligoqueto tubífido e o hospedeiro definitivo são as aves. Existe na literatura casos que descrevem o perigo que estas larvas representam para o ser humano, quando são ingeridas vivas ao comer-se peixe mal cozido.

Os nematódeos do gênero Capillaria são encontrados muitas vezes no intestino dos peixes de aquário, onde são capazes de provocar úlceras e edema .

Apesar de os trematódeos digenea adultos e nematóides habitarem a luz do intestino dos peixes, quase não causam doenças.

Os acantocéfalos são geralmente vermes cilíndricos longos, que não tem tubo digestivo e órgãos sexuais independentes, e necessitam de pelo menos um hospedeiro intermediário, que é um artrópode, para realizar o seu ciclo evolutivo. Os ovos, contendo uma larva, são eliminados do hospedeiro definitivo pelas fezes e este é ingerido por um artrópode, onde a larva se libera e alcança a cavidade abdominal. Se o peixe, hospedeiro definitivo, ingerir esse invertebrado, a larva torna-se adulta.

Os acantocéfalos são dotados de uma probócide de fixação, provida de ganchos, causando lesões localizadas na mucosa intestinal dos peixes. O Acanthocephalus jacksoni produz alto prejuízo para os cultivos de Salvelinus e truta arco-íris (Oncorhynchus mykiss), em função do grande número de úlceras com hemorragias e necrose.

Em espécies como o pacu e o piauçu, são freqüentes o encontro destes parasitos na luz intestinal. Quando a infestação é alta podem ser observados inclusive no estômago dos peixes.

\section{Doenças causadas por tênias}

Os cestóides são também endoparasitas que são encontrados no intestino do hospedeiro e necessitam ao menos de um hospedeiro, que pode ser intermediário ou definitivo. 
As larvas de cestóides são freqüentes nos peixes e muitas vezes formam cistos nas vísceras e na musculatura. Dentro da classe Cestoda incluem-se as famílias: Proteocephalidae, Pseudophyllidea, Tetraphyllidea, Trypanorhynchidea e Caryphyllidea.

Todos os cestóides são ovíparos e, portanto, eliminam seus ovos com as fezes do hospedeiro definitivo, os quais podem incubar-se na água e dar origem a uma larva nadadora. As larvas do coracídeo, dos cestóides $\mathrm{Di}$ phyllobothrium e da família Trypanorhynchidea, vivem num copepodídeo, que é o primeiro hospedeiro intermediário.

Nos outros grupos de cestódeos, parasitos dos peixes marinhos, os ovos são ingeridos pelo hospedeiro intermediário e a eclosão ocorre no intestino. Ingerido seja de uma forma, ou seja de outra, a larva atravessa a parede do intestino do hospedeiro e continua desenvolvendose na cavidade abdominal do peixe, sendo esse estádio conhecido como procercóide. Se esse é ingerido por um peixe apropriado, penetra através da parede intestinal e encista-se nas vísceras e na musculatura, onde se desenvolve até atingir o estado de plerocercóide. No Tetraphyllidea este desenvolvimento ocorre na luz do tubo digestivo do hospedeiro, que atua como intermediário secundário. O ciclo evolutivo desse grupo completa-se quando o hospedeiro intermediário secundário é ingerido por um hospedeiro definitivo, que pode ser um peixe, ave ou mamífero, em cujo intestino o parasito alcança o estádio adulto.

Nos cestódeos cariofileídeos e proteocefalídeos, o desenvolvimento até o estádio plerocercóide ocorre no hospedeiro intermediário invertebrado, um copepodídeo, e o ciclo evolutivo completa-se se este último for ingerido por um peixe hospedeiro apropriado, alojando-se no seu intestino, sem causar grandes prejuízos. Os proteocefalídeos são parasitos muito comuns nos peixes do mundo todo.

De todos os parasitos, as larvas plerocercóides são as de maior tamanho, cerca de $20 \mathrm{~cm}$. Entre eles estão os lingulídeos, cosmopolitas, que podem parasitar principalmente os ciprinídeos. Devido ao seu tamanho, podem produzir na cavidade abdominal do hospedeiro compressão e torção das vísceras, abdômen distendido e inibição do processo reprodutivo.

O parasita Bothriocephalus gowkongensis é um parasita da ordem Pseudophyllidea, medindo cerca de $20 \mathrm{~cm}$ de comprimento. Acomete carpa, principalmente aquelas com menos de um ano de idade e que se alimentam de plâncton. Os sintomas dessa enfermidade são: apatia, anorexia e abdômen distendido, podendo apresentar enterite hemorrágica com destruição do epitélio intestinal.

\section{Doenças causadas por crustáceos}

A argulose, a ergasiliose e a lerneose são doenças que acometem plantéis de peixes. Os agentes são os branquiureos (Argulus sp.) e os copepodídeos (Ergasilus $e$ Lernaea). São artrópodes por possuírem apêndices articulados e corpo coberto de quitina rígida ou semi-rígida, pertencentes à classe Crustácea. Provocam muitos danos e estão disseminados por todo o mundo. Sua fixação dá-se na superfície externa de peixes de água doce ou marinha.

Os copepodídeos apresentam ciclo evolutivo complexo, com vários estádios larvais diferentes. Os ovos eclodem e eliminam larvas nadadoras "nauplius" que passam por "nauplius" I, II, e "nauplius" III que origina o primeiro estádio de copepodídeo.

A prevenção destas doenças se faz adquirindo peixes certificados, uma vez que a erradicação é difícil .

\section{Argulose}

Os Argulus são ectoparasitas que se localizam em toda a pele e nadadeiras de muitas espécies de peixe (Figura 15). São chamados vulgarmente de "piolho do peixe". Possuem ganchos e ventosas que servem de órgãos de fixação e uma trompa que atua como órgão de alimentação. Esta trompa penetra na epiderme e nos tecidos subjacentes do hospedeiro. O ciclo é direto e os ovos são depositados na água, eclodindo e dando origem a uma forma nadadora, que deve encontrar o hospedeiro apropriado dentro de, no máximo, três dias. Passam de um peixe para outro e são responsáveis por altas infestações com grande mortalidade, principalmente nos peixes jovens. As lesões produzidas pelos Argulus podem necrosar, ulcerar e dar origem a uma infecção secundária. Esta doença acomete qualquer espécie de peixe, e as

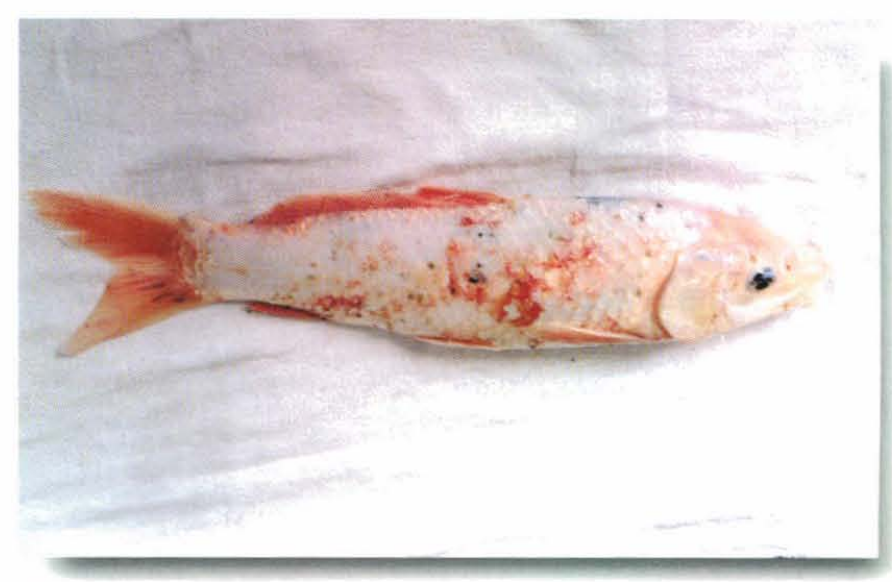

Figura 15 - Argulose em carpa . 


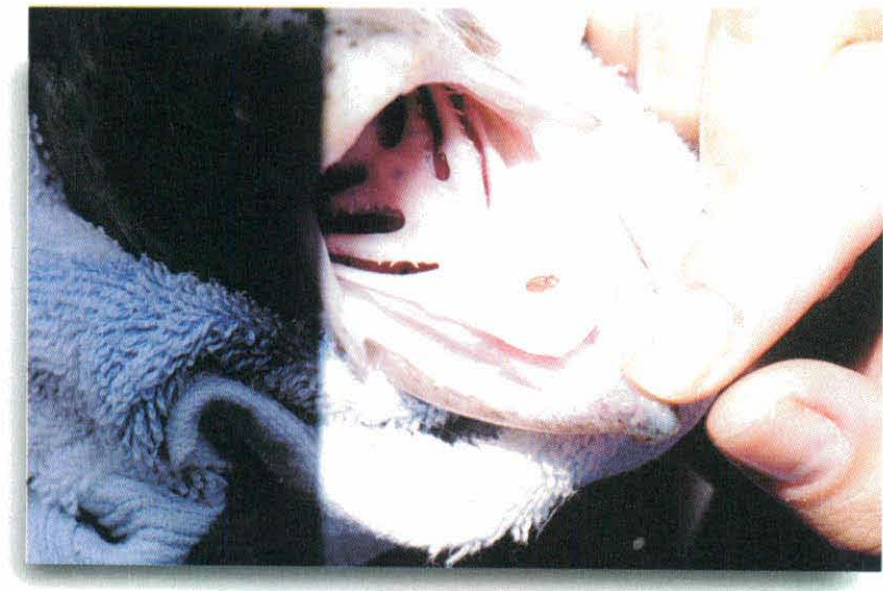

Figura 16 - Truta com Argulus no pálato.

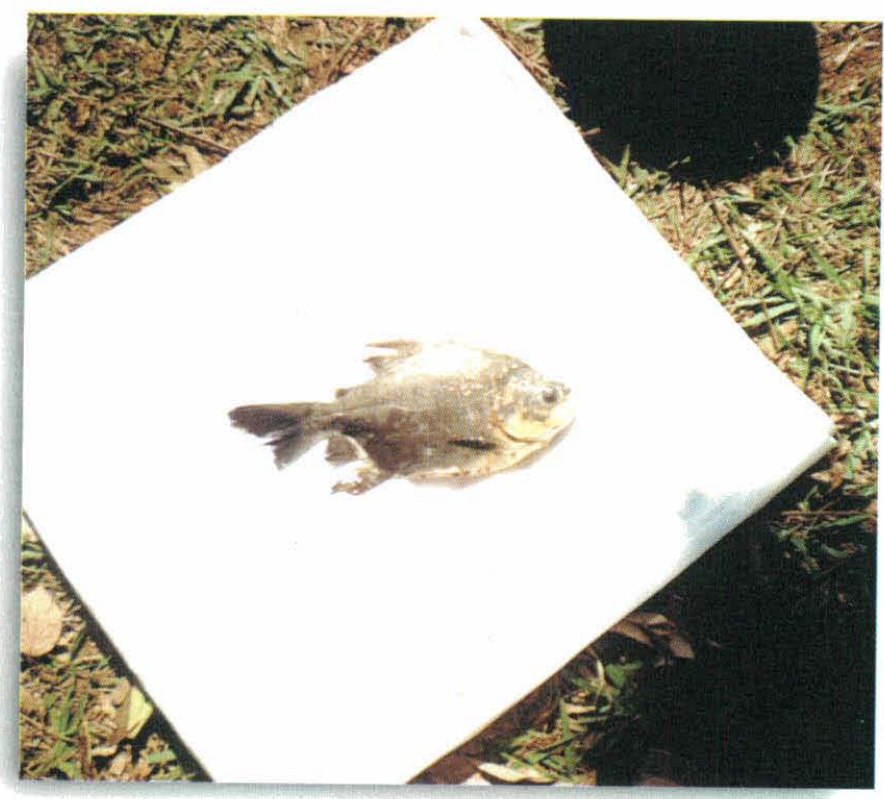

Figura 17 - Pacu com Argulus, superfície corporal.

espécies tropicais tornam-se susceptíveis quando submetidas a condições estressantes.

Em 1997, foram feitos dois diagnósticos de argulose: um em truta arco íris (ALEXANDRINO et al. 1999f. (no prelo), (Figura 16) e outro em pacu (Figura 17) por ALEXANDRINO et al. 1999d. (no prelo); em ambos ocorreram mortalidade.

\section{Lerneose}

Os copepodídeos são os crustáceos parasitas mais freqüentes em peixes, sendo o gênero Lernaea, da ordem Lernaeoidea, um dos mais perigosos para peixes jovens e alevinos de água doce e marinha. A espécie mais importante de água doce é a Lernaea cyprinacea, que não tem hospedeiro específico. A porção cranial desse parasito lembra uma âncora, e é a parte que penetra na musculatura do hospedeiro, às vezes, fixa-se no esôfago e estômago. O parasito produz lesão ulcerosa que serve de porta de entrada para infecções secundárias; outras vezes, forma no local um nódulo fibroso e avermelhado. Os peixes parasitados perdem peso e têm um aspecto desagradável.

ALEXANDRINO et al. (1999b) relataram a presença de lerneose em piauçu (Leporinus macrocephalus). A infestação foi controlada com o uso de organofosforado.

A reprodução da Lernaea ocorre somente em temperaturas acima de $14^{\circ} \mathrm{C}$, o que em regiões de clima quente, permitem ao copepodídeo dar origem a graves infestações durante todo o ano (Figura 18). A lerneose tem sido encontrada em todas espécies brasileiras sendo o pacu, tambaqui, tambacu e piauçu as espécies mais susceptíveis (Figura 19).

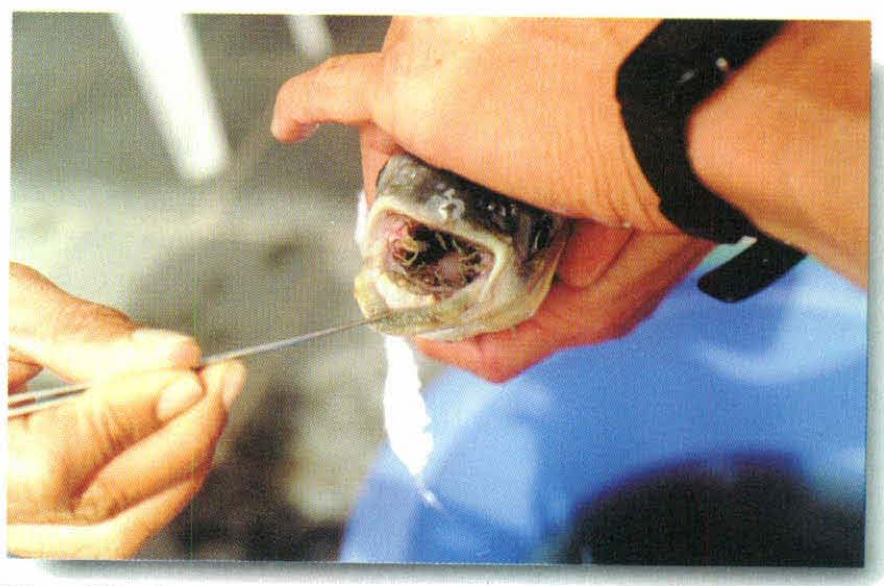

Figura18 - Lerneose em pacu.

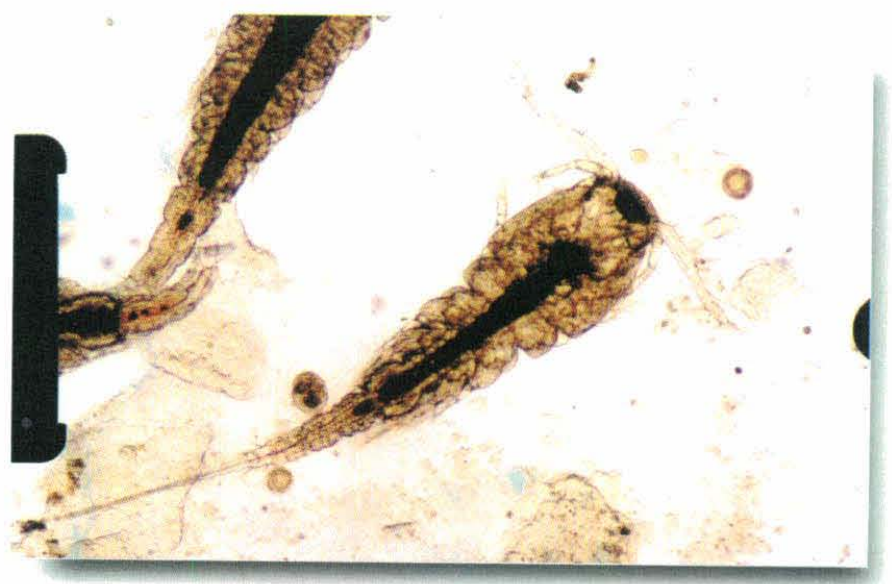

Figura 19 - Esfregaço de brânquias de pacu - Copepodídeo - Lernaea cyprinacea. 


\section{Ergasilidiose}

Os ergasilídeos localizam-se nas brânquias de muitas espécies de peixes de água doce e marinha. A reprodução desses parasitos ocorrem no verão, determinando altas infestações desta enfermidade nessa estação. Alimentam-se de células das brânquias e podem provocar anemia, além do que predispõem a infecções secundárias. Até o momento, não há registro da ocorrência dessa doença em nossas espécies, apesar de já ter sido encontrado o agente patogênico em peixes brasileiros.

\section{Outros Ectoparasitas}

A Piscícola geometra é uma sanguessuga de água doce que pode causar epizootia em cultivos de truta arco-íris e de ciprinídeos em tanques de terra. Este parasito, que mede ao redor de $2 \mathrm{~cm}$ de comprimento, fixa-se na pele do peixe, perfurando-a para se alimentar de sangue. Causa anemia, e as lesões provocadas são porta de entrada para as infecções secundárias. Este parasito pode transmitir protozoários sangüíneos para os peixes.

A profilaxia para evitar as doenças causadas por crustáceos é feita pela desinfecção dos tanques com cal, após cada ciclo produtivo (ALEXANDRINO, 1998).

\section{V - DOENÇAS NÃO-INFECCIOSAS}

Dentro desse contexto, os transtornos por fatores abióticos decorrem de falhas no manejo e podem ser classificados em físicos e químicos.

\section{Falta de oxigênio (hipóxia)}

Os peixes necessitam de uma quantidade mínima de oxigênio dissolvido na água para sobreviverem. Se o nível for abaixo do mínimo necessário, os peixes morrem asfixiados, porém, se a quantidade de oxigênio permanecer no nível mínimo necessário leva a diminuição ou ausência de crescimento dos peixes, aumento no coeficiente de transformação do alimento e incremento da sensibilidade frente às agressões.

Como medida preventiva deve-se estabelecer o número de peixes compatível com o teor de oxigênio dissolvido na água (densidade), controlar a renovação constante da água, controlar a taxa de arraçoamento, a quan- tidade de matéria orgânica e algas nos viveiros. Pode-se fazer uso de ventilação artificial para melhorar o teor de oxigênio dissolvido.

\section{Transtornos térmicos}

Como os peixes são animais ectotérmicos, a temperatura da água é vital para sua existência. A temperatura influencia todas as atividades fisiológicas do animal, como crescimento, respiração, alimentação, digestão, excreção, reprodução, produção de anticorpos, e de hormônios e natação. Os peixes tropicais quando submetidos a temperaturas baixas diminuem seu metabolismo geral, apresentam-se letárgicos, param de comer e interrompem o processo reprodutivo, podendo inclusive morrer (Figura 20). Os peixes de clima temperado, como por exemplo os salmonídeos, quando submetidos a temperaturas altas, também param de crescer, aumentam a taxa metabólica, levando-os à debilidade e à morte. Além do que, com a elevação da temperatura a quantidade de oxigênio fica diminuída, provocando maior susceptibilidade a doenças.

\section{Alcalose e acidose}

Os peixes apresentam melhor taxa de conversão quando estão em água com $\mathrm{pH} 7,0$ (pH neutro). Quando este pH está acima de 7,0, considera-se alcalino e abaixo de 7,0, ácido. A exigência quanto ao valor de $\mathrm{pH}$ depende do peixe que está sendo cultivado e das condições do meio para o cultivo.

As maiores causas de variação do $\mathrm{pH}$ do meio aquático são: subsolo de constituição calcárea e carbo- 


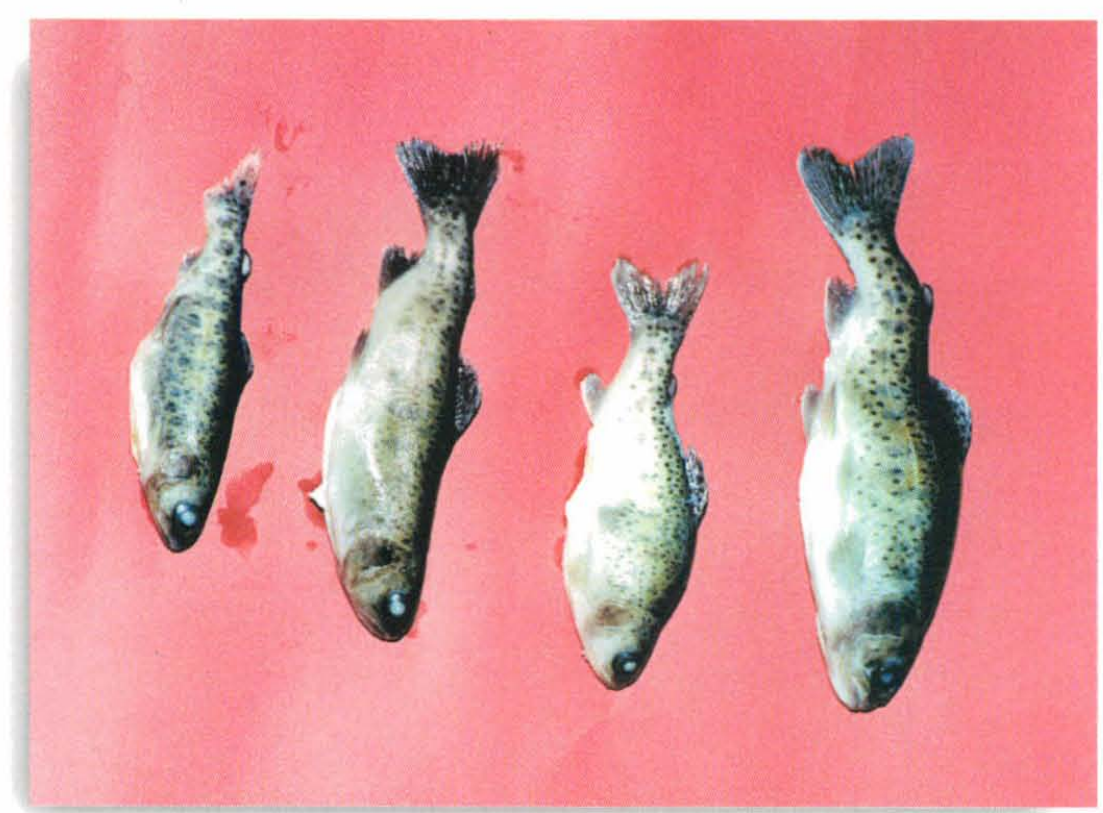

Figura 21 - Trutas arco-íris com lordose e escoliose.

natos, fotossíntese, renovações acidentais ou não de substâncias básicas, produção de amônia por trutas em tanques com densidade elevada, que provoca o aumento do $\mathrm{pH}$, enquanto que subsolos de regiões graníticas, chuvas ácidas, cobertura vegetal rica em resinas, renovações acidentais ou não de substâncias ácidas (indústrias processadoras de leite), gases acidificantes da atmosfera, tratamento com formol, entre outros, provocam diminuição do $\mathrm{pH}$.

Assim sendo, as espécies de peixes de água doce quando estão em pH acima de 8,0, mostram inicialmente sinais de intranqüilidade, movimentos bruscos e aumento na produção de muco; posteriormente, a pele pode apresentar hemorragias, as nadadeiras degeneram-se e apresentam queimaduras cáusticas nas brânquias, o que leva à morte por deficiência respiratória.

Esse quadro em piscicultura é sempre observado em viveiros que sofreram desinfecção ou calagem e não foram suficientemente enxaguados. Para evitar esse problema é necessário medir o $\mathrm{pH}$ da água antes de colocar os peixes. Se essa falha de manejo ocorrer, deve-se rapidamente trocar a água dos viveiros até atingir o $\mathrm{pH}$ próximo da neutralidade.

A acidose ocorre quando o $\mathrm{pH}$ da água está inferior a 6,0 , podendo causar grande mortalidade quando o $\mathrm{pH}$ desce até 5,5 . Os sintomas observados são semelhantes à alcalose, sendo diferenciados pela medição do $\mathrm{pH}$.

O controle é feito mediante adição de pequena quantidade de cal diluído na água do viveiro, para evitar que o $\mathrm{pH}$ não se altere bruscamente.

\section{Salinidade}

Os peixes podem resistir a concentrações variadas de sal no ambiente aquático. Quando a concentração encontra-se acima do seu limiar, surgem alterações como pápulas, hemorragias cutâneas puntiformes e lesões branquiais.

\section{Amônia}

É uma substância muito tóxica proveniente da decomposição orgânica e da excreção dos próprios peixes, que pode ser acentuada em águas alcalinas e com temperatura alta. A ação tóxica dessa substância lesa as brânquias e o intestino, sendo que os peixes pequenos são os mais susceptíveis.

\section{Doenças nutricionais}

Os peixes necessitam de boa alimentação, tanto em quantidade como em qualidade. Isso significa que, para os peixes estarem bem alimentados, é necessário dar-lhes uma ração que atenda as suas necessidades fisiológicas. Portanto, estas doenças referem-se àquelas causadas por desequilíbrios ou carências dos componentes da ração.

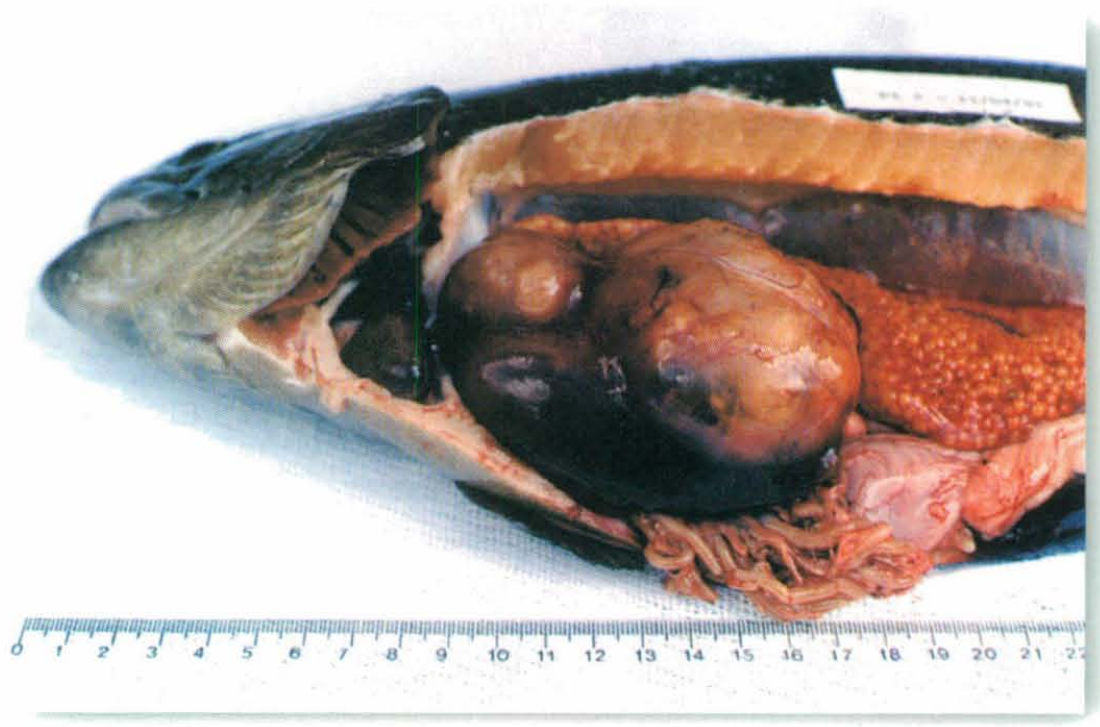

Figura 22 - Truta arco-íris com hepatocarcinoma. 
As doenças mais estudadas são causadas por deficiências vitamínicas, entre elas, as deficiências de vitamina $\mathrm{C}$, que é responsável pela presença de lordose e escoliose em truta arcoíris (Figura 21).

De um modo geral, nos peixes mantidos em cultivo, é comum, durante a necropsia, encontrar-se o fígado friável e de coloração acastanhada, e grande quantidade de gordura visceral, indicando estar havendo um desbalanceamento na ração fornecida.

Podem ocorrer outras doenças nutricionais causadas por deficiência de proteínas, ácidos graxos essenciais e minerais, e estão reunidas no quadro de resumo dos principais sintomas de deficiência nutricional.

\section{Doenças neoplásicas}

São doenças causadas por uma proliferação celular descontrolada. Podem ser classificadas como benignas e malignas. As causas que predispõem a estas alterações são: substâncias químicas, fatores imunológicos, genéticos, vírus, traumatismos repetidos por parasitas, radiações, entre outras.

As neoplasias não têm um significado econômico importante em piscicultura, uma vez que poucos exemplares podem desenvolvê-las, com a exceção das salmoniculturas, onde o carcinoma hepatocelular torna-se um grande problema que envolve principalmente reprodutores (ALEXANDRINO et al., 1996b), (Figura 22). Os salmões são altamente susceptíveis à aflatoxina, produzida pelo fungo $A s$ pergillus flavus, que se desenvolve em ração com validade ul-

\begin{tabular}{|c|c|c|}
\hline \multicolumn{3}{|c|}{ Resumo dos principais sintomas de deficiência nutricional e causas: } \\
\hline Escoliose/Lordose & $\begin{array}{l}\text { Deficiência de } \\
\text { Toxicidade por }\end{array}$ & $\begin{array}{l}\text { Triptofano } \\
\text { Magnésio } \\
\text { Fósforo } \\
\text { Vitamina C } \\
\text { Ácidos graxos essenciais (lordose) } \\
\text { Chumbo } \\
\text { Cádmio } \\
\text { Leucina } \\
\text { Vitamina A } \\
\text { Óleo de peixe oxidado }\end{array}$ \\
\hline Catarata & $\begin{array}{l}\text { Deficiência de } \\
\text { Toxicidade por }\end{array}$ & $\begin{array}{l}\text { Metionina } \\
\text { Triptofano } \\
\text { Zinco } \\
\text { Magnésio } \\
\text { Cobre } \\
\text { Selênio } \\
\text { Manganês } \\
\text { Vitamina A } \\
\text { Riboflavina } \\
\text { Colina } \\
\text { Óleo de peixe oxidado }\end{array}$ \\
\hline Erosão em nadadeira & $\begin{array}{l}\text { Deficiência de } \\
\text { Toxicidade por }\end{array}$ & $\begin{array}{l}\text { Lisina } \\
\text { Triptofano } \\
\text { Zinco } \\
\text { Riboflavina } \\
\text { Inositol } \\
\text { Niacina } \\
\text { Vitamina C } \\
\text { Chumbo } \\
\text { Vitamina A }\end{array}$ \\
\hline $\begin{array}{l}\text { Degeneração } \\
\text { Hepática }\end{array}$ & $\begin{array}{l}\text { Deficiência de } \\
\text { Toxicidade por }\end{array}$ & $\begin{array}{l}\text { Colina } \\
\text { Ácidos graxos essenciais } \\
\text { Óleo de peixe oxidado }\end{array}$ \\
\hline Exoftalmia & $\begin{array}{l}\text { Deficiência de } \\
\text { Toxicidade por }\end{array}$ & $\begin{array}{l}\text { Ácido Pantotênico } \\
\text { Niacina } \\
\text { Ácido fólico } \\
\text { Vitamina A } \\
\text { Vitamina E } \\
\text { Óleo de peixe oxidado }\end{array}$ \\
\hline $\begin{array}{l}\text { Hemorragia em } \\
\text { pele/ nadadeira }\end{array}$ & Toxicidade por & $\begin{array}{l}\text { Riboflavina } \\
\text { Ácido pantotênico } \\
\text { Niacina } \\
\text { Tiamina } \\
\text { Inositol } \\
\text { Vitamina C } \\
\text { Vitamina A } \\
\text { Vitamina K } \\
\text { Óleo de peixe oxidado }\end{array}$ \\
\hline
\end{tabular}


trapassada ou, então, malconservada, promovendo a formação de tumores.

\section{Malformações congênitas}

São decorrentes de anomalias genéticas ou do desenvolvimento embrionário. $\mathrm{O}$ animal pode apresentar crescimento retardado, cabeça atrofiada em relação ao corpo, falta de nadadeiras, olhos, boca, etc. Estas alterações são, em nossos plantéis, observadas comumente em carpas, pacus e tilápias, devido, possivelmente, à consangüinidade dos pais.

\section{Mortalidade devida a predadores}

Os predadores mais comuns que podem atacar principalmente larvas e alevinos de peixes são: larvas de libélulas, copepodídeos, moluscos, aves (martim pescador, garça, biguá) e mamíferos, como por exemplo, a lontra.

\section{TRATAMENTO DE DOENÇAS DE PEIXES}

Um plantel deve ser tratado somente após a elaboração e conclusão do diagnóstico. Para isso, é necessário o isolamento e a identificação do agente patogênico, e em se tratando de piscicultura, nem sempre o tratamento pode ser concretizado por ser, na maioria das vezes, antieconômico ou até mesmo inviável.

$\mathrm{O}$ tratamento dos peixes pode ser feito interna ou externamente. Quando o tratamento é feito de forma externa, pode-se utilizar a administração de drogas na água pelos seguintes métodos:

1) banhos de longa duração, onde os peixes são expostos ao medicamento até total renovação da água;

2) banhos de curta duração, nos quais os peixes são mantidos em uma solução medicamentosa de concentração elevada num período de 1 a 60 minutos.

Em qualquer um dos tratamentos há a necessidade de observação constante do plantel para detectar qualquer sintoma de intoxicação, como letargia ou excitação, traduzida por movimentos bruscos de natação e aceleração do ritmo respiratório. Nessas circunstâncias, a intervenção deve ser rápida, para que não ocorram eventuais contratempos, como por exemplo, a mortalidade.

Outra forma é o tratamento tópico utilizado para lesões externas no corpo, olhos e nadadeiras. Para sua realização, é importante que o animal esteja devidamente imobilizado, a fim de se evitar novos traumatismos. Essa forma é indicada para tratamento de indivíduos de alto valor econômico ou pequenos grupos de reprodutores.

As formas de se realizar tratamento por via interna são pelos alimentos, parenteral ou injetável.

Os medicamentos podem ser adicionados na ração que será oferecida aos peixes; desse modo, a absorção ocorrerá no intestino, alcançando a corrente sangüínea.

A administração parenteral, bem como a injetável, deve ser usada para tratar de indivíduos, ou para um pequeno grupo de peixes.

As doenças de peixes causadas por protozoários, com exceção da tricodiniose, podem ser tratadas com formol na forma de banho longo, 3 banhos 1:15.000 ou 1: 20.000 com intervalo de 30 horas, no mínimo, ou um único banho 1:4.000, durante 15 a 60 minutos (dependendo da susceptibilidade da espécie ao formol). $\mathrm{O}$ curimbatá (Prochilodus scrofa) mostrou-se altamente sensível a este produto químico. Durante o tratamento é necessário usar ventilação artificial na água para suprir deficiência de oxigênio, pois o formol é uma substância oxirredutora.

Para o controle da tricodiniose, dactilogiridose, girodactilose e doenças causadas por crustáceos, o organofosforado é o produto recomendado, desde que se use com cautela. Sempre que precisar usá-lo, é necessário conhecer bem a utilização da água da microbacia, para não contaminar outros animais como gado de leite, gado de corte, aves que estarão bebendo esta água e, até mesmo, a comunidade local que estará utilizando esta água. Outro aspecto legal, e que deve ser levado em consideração, é a contaminação da natureza, pois adicionar organofosforado diretamente na água para tratar os peixes é bastante comprometedor. A Alemanha desenvolveu um produto próprio para peixes com composição semelhante ao Neguvon ${ }^{\mathrm{R}}$; porém esse produto está em fase de teste (comunicação pessoal), não se tendo até o momento, conclusão deste trabalho.

O Neguvon ${ }^{\mathrm{R}}$ tem sido recomendado por REINCHENBACH - KLINKE (1982), na seguinte posologia: se o banho for longo, recomendam-se 3 a 4 banhos semanais, utilizando $0,1 \mathrm{~g} / \mathrm{m}^{3}$. Segundo a literatura, não foi encontrado resíduo após 24 horas nas espécies tratadas. Se a opção for pelo banho curto, a recomendação é um único banho utilizando $25 \mathrm{~g} / \mathrm{l}$ durante 5 minutos. Esse tratamento não é recomendado para pacu, pois a dose medicamentosa funciona como CL/100. Porém, este campo é totalmente novo para a medicina veterinária, estando aberto para a pesquisa, não só referente às doses como também para determinar períodos de carência de produtos medicamentosos. 
Para este tipo de tratamento, o período de carência para trutas e carpas é de 21 dias e até o momento, não se conhece o período residual para nossas espécies. É necessário conhecer a farmacocinética dos produtos em relação às diferentes espécies, às fases de desenvolvimento e também, à temperatura, para se usar adequadamente as drogas.

Em função do uso indiscriminado de produtos químicos no controle e na prevenção de doenças, do uso indevido de defensivos agrícolas e da contaminação por metais pesados, os países desenvolvidos tem rechaçado produtos de aqüicultura provenientes de países subdesenvolvidos.

Para a obtenção de produtos com qualidade apropriada para o consumo, é necessário aplicação de medidas preventivas, a fim de se evitar o uso irracional de medicamentos e, para isso, deve-se, à semelhança do que ocorre em países com uma piscicultura desenvolvida, investir no treinamento e capacitação de médicos veterinários, bem como no estabelecimento de centros de diagnóstico para doenças de organismos aquáticos.

Neste sentido, podemos afirmar que existe no país uma carência de laboratórios de referência para diagnóstico de doenças em organismos aquáticos, o que tem inviabilizado os estudos e levantamentos epidemiológicos.

Deve-se levar em conta, ainda, que os medicamentos, anti-sépticos e desinfetantes, a serem utilizados em piscicultura deveriam ser restritos e controlados no país pelo Ministério da Agricultura. Como a atividade ainda necessita de alguns ajustes importantes, este setor é mais um que merece atenção por parte das autoridades. Nos Estados Unidos, o controle de medicamentos é feito pela FDA. Acreditamos que, para a aqüicultura, possamos seguir as normas estabelecidas pelo FDA até ocorrer a normalização em nosso país.

Para colaborar com as autoridades sanitárias há necessidade urgente que a Medicina Veterinária passe a atuar efetivamente junto à essa atividade, visando a orientação dos produtores na profilaxia e na terapêutica, para que as drogas não sejam mais usadas irracionalmente.

\section{Conclusões}

1. As informações técnico-científicas, referentes à alimentação, nutrição, reprodução, farmacologia e terapêutica na aqüicultura em nosso meio ainda são precárias.

2. A falta de conhecimento técnico-científico faz com que a piscicultura não se modernize tecnologicamente; desta forma, a atividade apresenta baixa produtividade e subaproveitamento do pescado como alimento, proporcionando um aumento no custo de produção para o criador e aumento no preço final para o consumidor.

3. Há necessidade urgente de que, nos históricos escolares das Faculdades de Medicina Veterinária, sejam incluídas disciplinas que preparem os alunos para o cultivo de organismos aquáticos, para que estes possam atuar efetivamente neste segmento.

4. A falta de base de outros profissionais para diagnosticar doenças de peixes tem gerado conclusões levianas no meio como, por exemplo, a ausência de doenças bacterianas e víricas.

5. A falta de controle zoosanitário nas pisciculturas tem proporcionado ao consumidor um pescado com qualidade duvidosa.

\section{SUMMARY}

The objective of this article is to present to the veterinarians all the procedures related to fish breeding. It is a new area of work for these professionals which should be considered as a new reality. The importance of the presence of a veterinarian at the production site in order to warrant the quality of the product is emphasised. The main diseases, prophilaxis and treatment are reported.

Uniterms: fish, pathology, sanity.

\section{REFERÊNCIAS BIBLIOGRÁFICAS}

1 - ALEXANDRINO, A.C. Prevenção de Doenças em piscicultura, Boletim técnico do Instituto de Pesca n. 23, 1998, $45 \mathrm{p}$.
2 - AlEXANDRINO, A. C.; ARAÚJO, A. P.; CARVAlHES, T. M. P. A.; BLANDINO, V. C.; WAKASA, Y. S. Procedimentos de coleta de material para laboratório. Publica- 
ções do Colégio Brasileiro de Aqüicultura, n. 1, 1999a.

3 - ALEXANDRINO,A. C.; ARAUJO, A. P.; OKUMURA, M. P. M. Ocorrência de Chilodonelose em tilápias do Nilo (Oreochromis niloticus). Revista Brasileira de Medicina Veterinária. Rio de Janeiro, 1999a. (no prelo).

4 - ALEXANDRINO,A.C.; AYROSA, L.M.S.; OKUMURA,M.P.M.; PAULI,A.O.S.; LIUSON, E.; ROSA, M. B.; CARVALHAES, T. M. P. A. Infestação por Lernaea cyprinacea em cultivo semi-intensivo de piauçu (Leporinos macrocephalus) na região do Paranapanema. Hora Veterinária - v. 19, n. 109, 1999b.

5 - AleXANDRINO, A. C.; LUVIZOTTO, M. C. R.; MANDELLI JR., J.; ARANA, S.; TABATA, Y. A.; RIGOLINO, M. G. Seqüência temporal no surgimento de lesões hepáticas em truta arco-íris, Oncorhynchus mykiss (Osteichthyes, Salmonidae), em cultivo, com descrição histopatológica. Revista Ceres, v.44, n.255, p. 487-96, 1997.

6 - ALEXANDRINO, A. C.; MANDELLI JR., J.; RANZANI PAIVA, M. J. T.; EIRAS, A. C.; AYROSA, L. M. S.; CABRAL, I. P.; SILVEIRA, V. R. Metacercariose em plantel de tambacu: relato de caso. Revista Ceres, v. 43, n. 249, p.591-6, 1996a.

7 - ALEXANDRINO PEREZ, A. C.; MANDELLI JR., J.; TABATA, Y. A.; SILVEIRA, V. R. Papiloma bucal em truta arcoíris em cultivo intensivo. Revista Brasileira de Medicina Veterinária, v.19, n.2, p. 78-80, 1997.

8 - ALEXANDRINO, A. C.; OKUMURA, M. P. M.; BALDASSI, L.; ARAUJO, A. P.; GUENKA, A. Ocorrência de Aeromonas hydrophila em trutas arco-íris(Oncorhynchus mykiss). Boletim do Instituto de Pesca. São Paulo. 1999v. (no prelo).

9 - ALEXANDRINO, A. C.; OKUMURA, M. P. M.; BALDASSI, L.; TABATA, Y. A.; PAULI, A. O. S.; ARAUJO, A. P.; ROSA, M. B. Ocorrência de Edwardsiella tarda em trutas arco-íris (Oncorhynchus mykiss) em cultivo intensivo. Boletim do Instituto de Pesca. São Paulo. 1999c. (no prelo).

10 - ALEXANDRINO, A. C.; OKUMURA, M. P. M.; KURODA, C. K.; DIAS, E. P.; CARVALHAES, T. M. P. A. Ocorrência de Argulose em pacu (Piaractus mesopotamicus). Revista Brasileira de Medicina Veterinária. Rio de Janeiro.1999d. (no prelo).

11 - ALEXANDRINO, A. C.; OKUMURA, M. P. M.; KURODA, C. K.; GUENKA, A. Nefrocalcinos em truta arco-íris (Oncorhynchus mykiss), cultivada em sistema intensivo. Revista Brasileira de Ciência Veterinária. Rio de Janeiro. 1999e. (no prelo).

12 - ALEXANDRINO, A. C.; PINTO, C. S. R. M. Ocorrência de Ichthyobodo necator em alevinos de "pacu" (Piaractus mesopotamicus Homberg, 1887), de criatório.
Revista Brasileira de Medicina Veterinária. v.20, n. 2, 1998 .

13 - ALEXANDRINO, A. C.; RANZANI PAIVA, M. J. T.; ARANA, S.; MANDELLI JR., J.; CARVALHO, M. H. Relato de carcinoma hepatocelular em tainha, Mugil platanus, da região estuarino-lagunar de Cananéia, Estado de São Paulo. Revista Brasileira de Medicina Veterinária, v.18, n. 5, p. 206-10, 1996b.

14 - ALEXANDRINO, A. C.; RANZANI PAIVA, M. J. T.; ISHIKAWA, C. M.; ARANA, S.; MANDELLI J.R., J.; EIRAS, A. C. Infestação aguda por Henneguya sp. (Protozoa, Monogenea) e Dactylogyridae (Platyhelminthes, Monogenea) em pacu Piaractus mesopotamicus Holmberg, 1887 (Osteichthyes, Characidae). Boletim do Instituto de Pesca, v.22, n.2, p.115-9, 1995.

15 - ALEXANDRINO, A. C.; RANZANI-PAIVA, M. J. T.; ROMANO, L. A. Identificación de viremia primaveral de la carpa en Carassius auratus, en San Pablo, Brasil. Revista Ceres, v. 45, n.358, p.125-37, 1998.

16 - ALEXANDRINO, A. C.; RIGOLINO, M. G.; OKUMURA, M. P. .M.; CARVALHO,V.A.; ARAUJO, A. P.; LIUSON, E. Ocorrência de Argulose em trutas arco-íris (Oncorhynchus mykiss). Boletim do Instituto de Pesca. São Paulo. 1999f. (no prelo).

17 - AXELROD, H. R. Handbook of fish diseases. T.F.H. Publications, $1989,160 \mathrm{p}$.

18 - BRUNO, D. W.; POPPE, T. T. A. Colour atlas of salmonid diseases. London: Academic Press, 1996, 194p.

19 - BURKA, J. F.; HAMMELL, K. L.; HORSBERG, T. E.; JOHNSON, G. R.; RAINNIE, D. J.; SPEARE, D. J. Drugs in salmonid aquaculture - A review. J. vet. Pharmacol. Therap., v.20, p. 333-49, 1997

20 - CARNEVIA, D. Enfermedades de los peces ornamentales. Buenos Aires: Agrivet, 1993, 319 p.

21 - CORDEIRO, N. S.; ARTIGAS, P. T.; GIÓIA, I.; LIMA, R. S. Henneguya pisciforme N. SP., mixosporídeos parasita de brânquias de lambari Hyphessobrycon anisitsi (Pisces, Characidae). Mem. Inst. Butantã, v. 47, n. 48, p. 61-9,1 983/84.

22 - COSTA A. B. Bactérias patogênicas em cultivo de peixes. Boletim informativo da ABRAPOA, v.8, n.11,1997.

23 - EIRAS, J. C. Elementos de ictioparasitologia. Porto: Fundação Eng. Antonio de Almeida, 1994, 339 p.

24 - EIRAS, J. C.; RANZANI PAIVA, M. J. T.; ISHIKAWA, C. M.; ALEXANDRINO, A. C.; EIRAS, A. C. Ectoparasites of semi-intensively farmed tropical freshwater fish Piaractus mesopotamicus, Prochilodus linneatus and Colossoma 
macropomum in Brazil. Eur. Ass. Fish. Pathol., v.15, n. 5 , p.148-51, 1995.

25 - EIRAS, J. C.; SOUZA, J. A.; ALEXANDRINO, A. C.; ISHIKAWA, C. M.; RANZANI PAIVA, M. J. T.; EIRAS, A. C. Preliminary bacteriological evaluation of intensively farmed fish (Piaractus mesopotamicus, Prochilodus scrofa and Colossoma macropomum) in São Paulo State, Brazil. Revista Unimar, v. 18, n.2, p. 299-306, 1996.

26 - FERRAZ, I. O. O que era só alternativa virou um negócio lucrativo. A Granja do Ano. p. 52-6, 1995/96.

27 - HERBERT, R. A. Handbook of fish diseases, T.F.H. Publications, $1989,160 \mathrm{p}$.

28 - ISHIKAWA, C. M. - Quantificação bacteriana e avaliação das lesões em peixes da espécie Oreochromis niloticus (tilápia do Nilo) inoculados experimentalmente com Mycobacterium marinum ATCC 927. São Paulo, Dissertação (Mestrado). Faculdade de Medicina Veterinária e Zootecnia da Universidade de São Paulo. 1998, 64p.

29 - KINKELIN, P. de; MICHEL, C.; GUITTINO, P. Tratado de las enfermedades de los peces. Zaragoza: Acribia, 1991, $353 \mathrm{p}$.

30 - MC LEAY D. J.; GORDON, R. Leucocrit: a simple hematological techinique for measuring acute stress in salmonid fish, including stressful concentrations of pulpmill effluent. J Fish. Res.Board. Can., v.34, p.2164-75, 1997.

31 - MESQUITA, E. F. M. Cultivo consorciado de peixes na República Popular da China. Revista de Pesca e Pescado. v.1, n.1, p.17-9, 1996.
32 - NOGA, E. J. Fish disease. Saint Louis: Mosby, 1996, $367 p$.

33 - OIE, Diagnostic manual for aquatic animal diseases, Paris: OIE, 1995, 194p.

34 - REICHENBACH KLINKE, H. H. Enfermedad de los peces. Zaragoza: Acribia, 1982, 507 p.

35 - ROBerts, R. J. Patologia de los Peces. Madri: Mundi Prensa, 1981, $366 \mathrm{p}$

36 - SCOTT, P. Therapy in aquaculture. In: BROWN, L. (ed.) Aquaculture for veterinarians: fish husbadry and medicine. Oxford: Pergamon, 1993, p. 131-52.

37 - STOSKOPF, M. K. Fish medicine. Philadelphia: W. B. Sauders, $1993,882 \mathrm{p}$.

38 - TACON, A. G. J. Nutritional fish pathology - A handbook of morphological signs of nutrient deficiency and toxicity in farmed fish. Roma: FAO, 1992, $75 \mathrm{p}$.

39 - TEIXEIRA FILHO, A. R. Ocorrência da bactéria Pseudomonas punctata (Zimmermann). Schaperclaus em peixes ornamentais, Carassius auratus L., e carpas Cyprinus carpio L., no Brasil. Bol.Inst.Pesca, v.4, n.3, p.37-42. 1975.

40 - TEIXEIRA FILHO, A. R. Piscicultura ao alcance de todos. São Paulo: Nobel, 1991, 212 p.

41 - WEDEMEYER G, A, MC LEAY, D. J. Methods for determining the tolerance of fishes to environment stressors. In: PICKERING, A. D. Stress and fish, London: Academic Press, 1981, p.247-75.

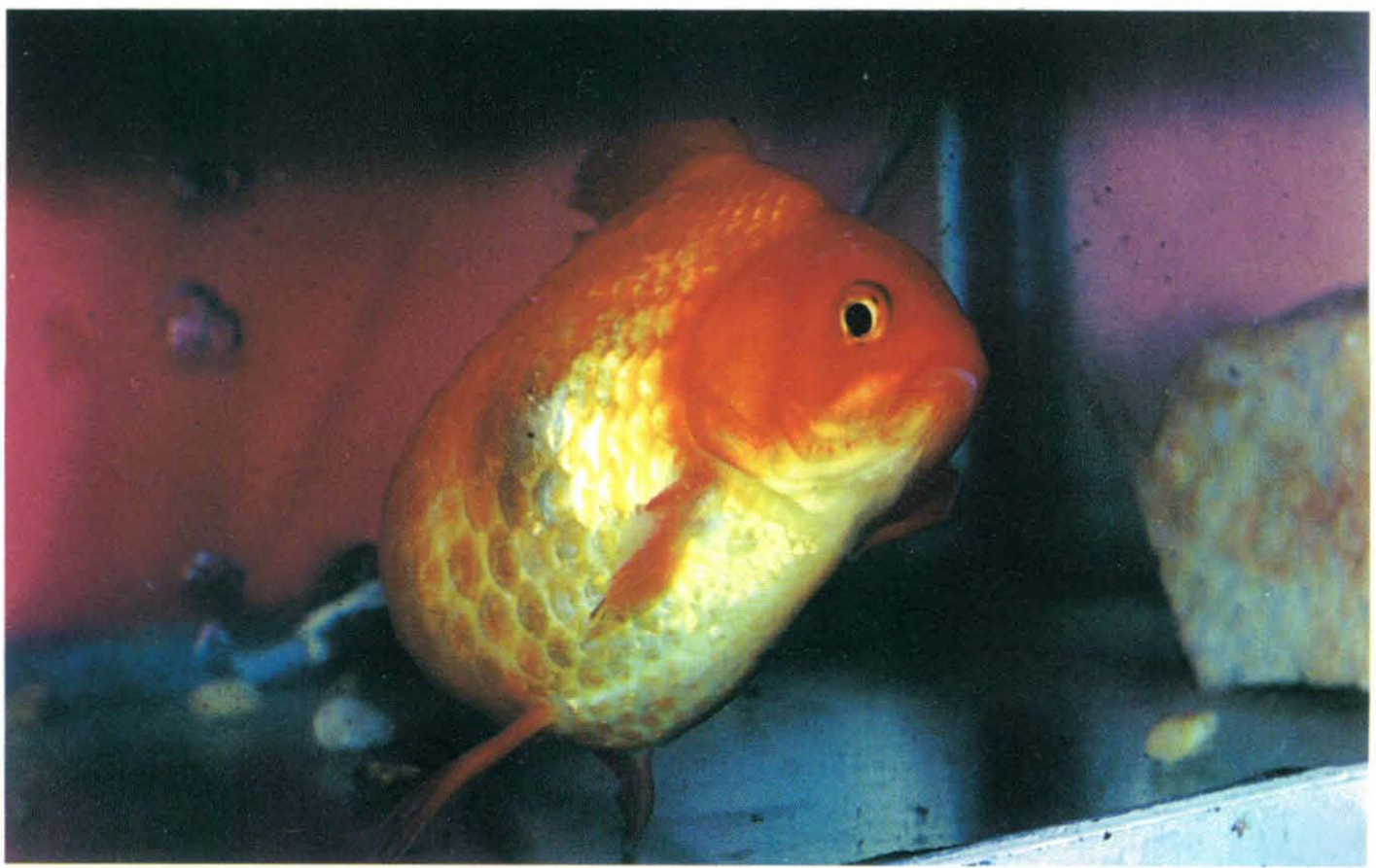

